\title{
Comparative 4E and advanced exergy analyses and multi-objective optimization of refrigeration cycles with a heat recovery system
}

\author{
K. Golbaten Mofrad ${ }^{1,2}$ S. Zandi ${ }^{1,2}$, G. Salehi ${ }^{3}$, M H Khoshgoftar Manesh ${ }^{1,2 *}$ \\ 1. Energy, Environment and Biologic Research Lab (EEBRLab), Division of Thermal Sciences and Energy \\ Systems, Department of Mechanical Engineering, Faculty of Technology \& Engineering, University of Qom, \\ Qom, Iran \\ 2. Center of Environmental Research, University of Qom, Iran \\ 3. Department of Mechanical Engineering, Central Tehran Branch, Islamic Azad University, Tehran, Iran \\ E-mail: $\underline{\text { m.khoshgoftar@qom.ac.ir }}$
}

\begin{abstract}
This paper aims to provide comprehensive 4E (energy, exergy, exergoeconomic, and exergoenvironmental) and advanced exergy analyses of the Refrigeration Cycle (RC) and Heat Recovery Refrigeration Cycle (HRRC) and comparison of the performance with R744 (CO2) and R744A (N2O) working fluids. Moreover, multi-objective optimization of the systems has been considered to define the optimal conditions and the best cycle from various perspectives. In HRRC, heat recovery is used as a heat source for an organic Rankine cycle. The energy and exergy analysis results show that utilizing HRRC with both refrigerants increases the coefficient of performance (COP) and exergy efficiency. COP and exergy efficiency for HRRC-R744 have been obtained 2.82 and 30.7\%, respectively. Due to the better thermodynamic performance of HRRC, other analyses have been performed on this cycle. Exergoeconomic analysis results show that using R744A leads to an increase in the total product cost. Total product cost with R744 and R744A have been calculated by $1.56 \$ / \mathrm{h}$ and $1.96 \$ / \mathrm{h}$, respectively. Additionally, to obtain the processes' environmental impact, Life Cycle Assessment (LCA) is used. Exergoenvironmental analysis showed that using R744A increases the product environmental impact by $32 \%$. Owning to the high amount of endogenous exergy destruction rate in the compressor and ejector compared to other equipment, they have more priority for improvement. Multi-objective optimization has been performed with exergy efficiency and total product cost objective functions as well as COP and product environmental impact for both refrigerants, which indicates that HRRC-R744 has better performance economically and environmentally. In optimal condition, the value of exergy efficiency, total product cost, COP, and the product environmental impact have been accounted for by $28.51 \%, 1.44 \$ / \mathrm{h}, 2.76$, and 149.01 $\mathrm{mpts} / \mathrm{h}$, respectively.
\end{abstract}

Received 8 June 2020, Revised 9 August 2020, Accepted 12 August 2020

Keywords: Refrigeration Cycle; exergy; exergoeconomic; exergoenvironmental; advanced exergy analysis; multiobjective optimization.

\section{Introduction}

Nowadays, using carbon dioxide $\left(\mathrm{CO}_{2}\right)$ as a refrigerant is remarkable because of not being toxicant, non-ignition, having low costs, and not being dangerous for the environment. Using an ejector as an expander instead of expansion device in compression refrigeration cycles has been started since 1990. The results indicate that using the ejector causes a decrease in the destruction of the expansion process and an increase in the refrigeration cycle capacity.

Demirel[1] have summarized some significant recent research on diverse aspects of thermodynamic analysis. In this study, exergy and exergoeconomic analysis of refrigeration cycles and waste heat utilization has been considered particularly. Ipakchi et al.[2]have assessed thermoeconomic and have checked the key parameters in the operation of combined cooling, heating, and power (CCHP) system with an ejector refrigeration cycle and $\mathrm{CO}_{2}$ working fluid. Miran et al. [3] have studied a refrigeration system in terms of exergy and thermoeconomic with three refrigerants include R744, R744A, and R170, as the working fluid of the cycle. Seckin[4] has studied the parametric analysis of two ejector refrigeration cycles with constant area ejector and constant pressure ejector. Moreover, in another paper, a
Kalina cycle has been coupled to an ejector refrigeration system to generate cooling and power concurrently [5]. Ahmadzadeh et al.[6]have checked and optimized the power production system and new ejector refrigeration system with solar energy in terms of exergoeconomic. Rostamnejad et al. [7]have presented a new ejector refrigeration cycle and started analyzing exergy and optimizing. The system's operation has been compared for six appropriate refrigerants. Megdouli et al.[8]have compared a new ejector refrigeration system with a conventional vapor compression system. In the proposed system, refrigerant $\mathrm{CO}_{2}$ has been used, and exergy analysis has been done. They have also evaluated the impact of adding an organic Rankine cycle (ORC) to the ejector refrigeration system in another article [9]. In this system, the loss of heat is used for producing vapor in the ejector refrigeration cycle. Nemati et al. [10]have investigated a two-stage ejector-expansion transcritical refrigeration cycle in terms of thermoeconomic and environmental. Moreover, the three working fluids, $\mathrm{CO} 2, \mathrm{~N} 2 \mathrm{O}$, and ethane, have been compared to the system's refrigerants. Momeni et al.[11]have compared three different refrigeration systems with natural working fluids from a thermodynamic, economic, and environmental perspective. Khanmohammadi et al. [12] have 
optimized a cascade refrigeration system with $\mathrm{CO}_{2}$ refrigerant. The cooling capacity of the system and the annual cost rate are considered as objective functions. Golbaten Mofrad et al.[13] have conducted 4E analyses for a cascade refrigeration system with natural working fluids. The cycle's multi-objective optimization has been done utilizing the objective functions of exergy efficiency, product cost rate, energy efficiency, and product environmental impact on finding the system's optimal operating conditions. Megdouli et al. [14]have investigated three different refrigeration cycles like vapor compression cycle, combined refrigeration cycle, and new combined refrigeration cycle to produce power and cooling in terms of energy, exergy, and exergoeconomic. Ghorbani et al.[15] have proposed a new ejector refrigeration cycle with photovoltaic-thermal collectors and phase change material storage and have evaluated in terms of energy, exergy, and economic analyses. Sheikhi et al.[16]have considered advanced exergy evaluation as a tool to split the exergy destruction of the refrigeration system to achieve a better perspective about the potentials of a system for improvements. Bai et al. [17] have evaluated the advanced exergy of an ejector refrigeration system with refrigerant R744. The major part of the exergy destruction of the system is endogenous. Moreover, they have analyzed the thermodynamic and advanced exergy of an improved ejector enhanced auto-cascade freezer cycle in another paper[18]. Chen et al.[19]have compared five refrigerants for the ejector refrigeration cycle in terms of energy, conventional exergy, and advanced exergy. Ghazizadeh et al.[20]have evaluated an integrated cryogenic process consist of three refrigeration cycles from advanced exergy and exergoeconomic. Moghimi et al. [21] have checked a CCHP cycle, including a Brayton cycle, Rankine cycle, and an ejector refrigeration cycle by using the 4E (energy, exergy, exergoeconomic and exergoenvironmental) analysis. Sanaye et al. [22] have presented a new refrigeration system, a combination of a vapor compression refrigeration cycle and an ejector refrigeration cycle. Zhao et al. [23] have done conventional exergy and advanced exergy analysis for both the ejector refrigeration cycle and the compressor refrigeration cycle. Esmaeilzadehazimi et al. [24]analyzed an MHD-Magneto hydrodynamic- cycle using 4E analysis. In MHD cycles, the vast amount of heat loss is recoverable, and it can be used as a heat source in the Brayton cycle by considering the operating temperature. Sanaye et al.[25] have investigated a CCHP system from the $4 \mathrm{E}$ viewpoint. The proposed system consists of a gas turbine, a heat recovery steam generating, and an absorption refrigeration system. Adibhatla et al.[26]have used $4 \mathrm{E}$ analysis for the investigation of a thermal power plant system. Energy and exergy efficiencies, economic parameters, and environmental parameters such as reducing coal consumption and $\mathrm{CO}_{2}$ production were determined. Jahangiri et al.[27] have evaluated the effects of Heller cooling tower performance and 4E analysis of a steam power plant for 24 climatic conditions. Gullo et al.[28]have evaluated the thermodynamic and advanced exergy analysis of a $\mathrm{CO}_{2}$ commercial refrigeration system. The use of $\mathrm{CO}_{2}$ refrigeration systems has become particularly important due to the importance of using environmentally friendly technologies. Modabber et al.[29]have conducted a 4E analysis for a desalination unit with a power and water cogeneration plant. Life Cycle Assessment (LCA) has been used for exergoenvironmental analysis.
Previous research has shown that the use of heat waste in thermodynamic systems is of great importance. Accordingly, this paper first compares the two cycles of RC and HRRC from thermodynamics' first and second laws. Thus, the two cycles' cooling load is the same and equal to $100 \mathrm{~kW}$, but the most important difference between these two cycles is in using heat recovery instead of the heat exchanger to recover heat from the desired cycle and then generate power using a turbine. To make the calculations more accurate, two working fluids, R744 and R744A, have been used for both refrigeration cycles. The most significant reason for utilizing these fluids is their compatibility with the environment. Furthermore, some of these refrigerants' properties, such as molecular weight, critical pressure, and temperature, are similar, and using them in refrigeration systems has been considered in recent years. Life cycle Assessment (LCA) has been used in most recent papers carried out exergoenvironmental analysis. LCA is a methodology for assessing environmental impacts associated with all the stages of the life cycle of system's equipment. Therefore, LCA has been exploited in this study.

Nowadays, in addition to the lack of consumer resources in setting up thermodynamic cycles, economic and environmental problems have also created limitations for designers. Accordingly, after comparing the results of energy and exergy analysis for the two cycles and determining the advantages of HRRC over RC, using the heat recovery for both R744 and R744A working fluids has been determined. Studies conducted in this matter show that economic and environmental analysis on heat recovery cycles requires further research. One of the present work's novelties is a comprehensive 4E analyses and advanced exergy analysis considering different natural working fluid and comparison. Another novelty aspect of this study is multi-objective optimization of the cycles with diverse objective functions based on efficiency, exergoeconomic, and exergoenvironmental.

\section{System Description}

At first, Gay et al.[30]has presented a simple model of the ejector refrigeration cycle(RC), which includes a compressor, heat exchanger, evaporator, separator, expansion valve, and ejector, according to Figure 1(a). Outlet pressure of the ejector has a considerable decrease, and it causes increasing the suction pressure in the compressor and makes the power consumption low in the compressor. Therefore, using an ejector helps decrease fuel consumption, and it is ideal economically. In this research, R744 and R744A are used as the working fluid of the refrigeration cycle. In this cycle, at first, refrigerant arrives at the compressor suction and then with a higher temperature and pressure enters the heat exchanger, and this equipment sends the extra heat out, and it causes decreasing the temperature of the refrigerant before entering the ejector. Thus, the ejector's pressure is decreased and turn to a combination of vapor and liquid. In order to separate these phases, the separator is used. Its work is to send the vapor phase into the compressor and the liquid phase into the expansion valve. The expansion valve causes a decrease in pressure; the result is a drop in temperature. Then refrigerant enters the evaporator, absorbs the environment heat, and at the end, enters the ejector. 


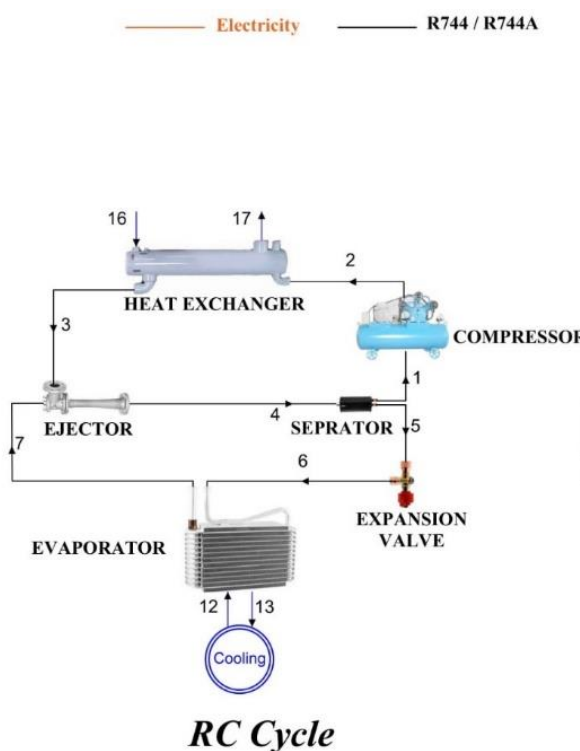

(a)

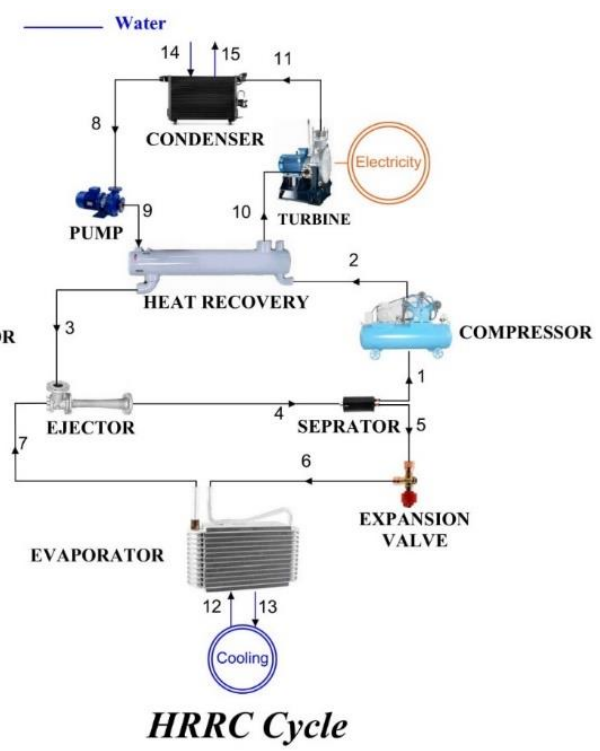

(b)

Figure 1. Schematic diagram of the HRRC and RC [9].

The thermodynamic analysis, which has been done on the RC, indicates that considerable heat is sent out of the cycle by the heat exchanger. If this heat is recovered, it could be used to install a Rankine cycle. As it is shown in Figure 1(b), three equipment includes; turbine, pump, and condenser are attached to the RC by heat recovery and form HRRC. The waste heat of the RC provides the needed heat for superheating the turbine's inlet refrigerant. After that, producing the power exits the turbine, and refrigerant enters the condenser. The P-h diagrams of RC and HRRC cycles are shown in Figure 2. In this figure, variations in enthalpy and pressure of two cycles, according to Figs. 1(a) and 1(b) have been illustrated. The stream numbers indicated in the Figure2 is related to Figure 1 (b). However, stream numbers of 1 to 8 are similar between Figure 1(a) and Figure 2(b).

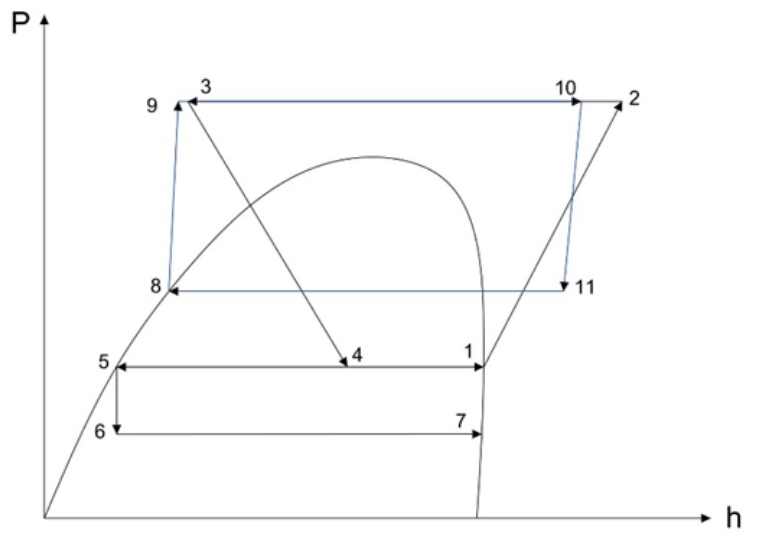

Figure 2. P-h diagram of the HRRC and RC.

\section{Thermodynamic Modeling and Assumptions}

Energy and exergy analysis of (RC) and (HRRC) cycles have been done using MATLAB and REFPROP software. Input parameter values for modeling refrigeration cycles with working fluids R744 and R744A are given in Table 1 .

\subsection{Assumptions}

In the present study, some assumptions are considered for analyzing the RC and HRRC [9, 31, 32]

1. Steady-state conditions
2. Input parameter values are the same for both cycles with working fluids R744 and R744A.

3 . The cooling capacity that is produced by the evaporator is considered as a constant value of $100 \mathrm{~kW}$.

4. The friction of each equipment is ignored.

5. The ejector is working adiabatically.

6. Kinetic energy and Potential energy changes are not considered.

Table 1. Input parameter values for analysis.

\begin{tabular}{ll}
\hline Input parameters & Values \\
\hline Turbine inlet pressure (kPa) & 9750 \\
Ejector inlet temperature(K) & 313 \\
Evaporator outlet temperature(K) & 278 \\
Diffuser efficiency (\%) & 75 \\
Nozzle efficiency (\%) & 80 \\
Mixture efficiency (\%) & 80 \\
Turbine isentropic efficiency (\%) & 80 \\
Pump isentropic efficiency (\%) & 80 \\
Compressor isentropic efficiency (\%) & 70 \\
Compressor outlet pressure (kPa) & 9750 \\
Environment pressure (kPa) & 101.3 \\
Ambient temperature(K) & 298 \\
System operating Time (hour) & 8760 \\
Component lifetime (year) & 20 \\
Cooling load(kW) & 100 \\
\hline
\end{tabular}

\subsection{Energy Modeling}

All the considered equipment should follow the specified control volume that is available in the steadystate conditions. According to the Eq. (1), $\dot{\mathrm{m}}_{\mathrm{i}}$ and $\dot{\mathrm{m}}_{\mathrm{e}}$ are inlet and outlet mass flow rates in the control volume, respectively[33].

$$
\begin{aligned}
& \sum \dot{m}_{i}+\sum \dot{m}_{e}=\frac{d m_{c . v}}{d t} \\
& \sum \dot{m}_{i}=\sum \dot{m}_{e}
\end{aligned}
$$

In addition, the condition of exchanging heat and work for the refrigeration cycle has considered as Eq. (3) that $\dot{Q}$ and $\dot{W}$ are the exchanged heat and work in available boundary conditions for the cycle[33]. 


$$
\dot{Q}^{+} \sum(\dot{m} h)_{i}=\dot{W}+\sum(\dot{m} h)_{e}
$$

The compressor's consuming work and the outlet work of the turbine are calculated by Eq. (4) and Eq. (5) respectively. The absorbed heat by the evaporator determined according to Eq. (6)[33].

$$
\begin{aligned}
& \dot{W}_{\text {Compressor }}=\dot{m}_{1}\left(h_{2}-h_{1}\right) \\
& \dot{W}_{\text {Turbine }}=\dot{m}_{10}\left(h_{10}-h_{11}\right) \\
& \dot{Q}_{\text {Evaporator }}=\dot{m}_{6}\left(h_{7}-h_{6}\right)
\end{aligned}
$$

The ejector includes three sections: nozzle, mixing chamber, and diffuser section and the flow transmission in them is steady-state and adiabatic. The efficiencies of the nozzle, mixing chamber, and diffuser section are given in Table.1. The schematic of the ejector is shown in Figure3.

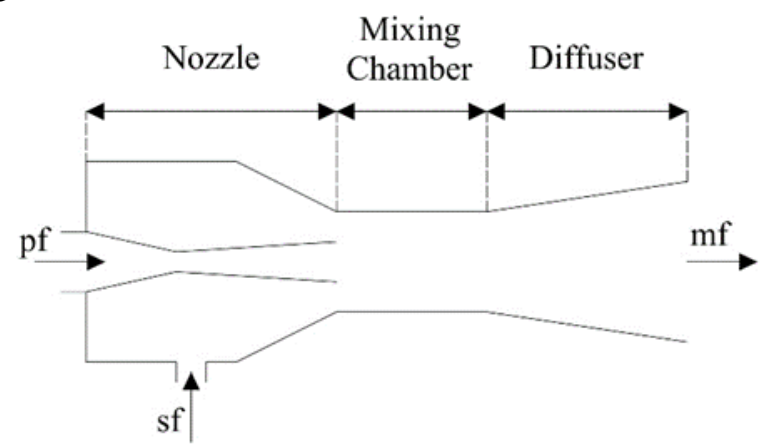

Figure 3. The schematic of the ejector.

The ejector has been modeled according to the conservation of mass, momentum, and energy equations. The equations used for modeling of the ejector are given in Table 2.

One of the most important criteria for analyzing the operation of refrigeration cycles is using the coefficient of performance (COP) that is defined as a ratio of the system's cooling capacity to the input operation of the cycle. The evaporator's cooling capacity is the same for both refrigeration cycles, but their pure work is different according to the outlet pressure of the turbine. Mathematical equations to calculate $\mathrm{COP}$ for the $\mathrm{RC}$ and HRRC are given in Eq. (7) and Eq. (8), respectively[33].

$$
\begin{aligned}
& C O P_{R C}=\frac{\dot{Q}_{\text {Evaporator }}}{\dot{W}_{\text {Compressor }}} \\
& C O P_{H R R C}=\frac{\dot{Q}_{\text {Evaporator }}}{\dot{W}_{\text {Compressor }}+W_{\text {Pump }}-W_{\text {Turbine }}}
\end{aligned}
$$

\subsection{Exergy Modeling}

The system's total exergy is divided into two sections, physical exergy and chemical exergy that can be calculated by Eq. (9)[34].

$$
\dot{E} X_{\text {Total }}=\dot{E} X_{P h}+\dot{E} X_{C h}
$$

Because there is no chemical reaction in cycles, the chemical exergy is considered zero.

$$
\dot{E} X_{C h}=0
$$

The exergy balance equation is defined as Eq.(11), according to the rate of fuel exergy $\left(E X_{F . k}\right)$ and product Exergy $\left(\dot{E} X_{P . k}\right)[33]$.

$$
\dot{E} X_{F: k}=\dot{E} X_{P, k}+\dot{E} X_{D, k}+\dot{E} X_{L, k}
$$

The rate of physical exergy determined according to Eq. (12) also exergy destruction ratio and exergy efficiency for each of the equipment calculated as Eq. (13) and Eq. (14)[34].

$$
\begin{aligned}
\dot{E} X_{p h} & =\dot{m}\left[\left(h-h_{0}\right)-T_{0}\left(s-s_{0}\right)\right] \\
Y_{D, K} & =\frac{\dot{E} X_{D, K}}{\dot{E} X_{D, t o t a l}} \\
\eta_{E X, k} & =\frac{\dot{E} X_{P, k}}{\dot{E} X_{F, k}}
\end{aligned}
$$

The exergy efficiencies of the refrigeration systems are determined as Eq. (15) and Eq. (16) for RC and HRRC cycles according to the exergy of fuel and product[35].

$$
\begin{gathered}
\eta_{E X, \text { Total }, R C}=\frac{\dot{E} X_{P, \text { Total }, R C}}{\dot{E} X_{F, \text { Total }, R C}} \\
\eta_{E X, \text { Total }, R C}=\frac{\dot{E} X_{P, \text { Total,HRRC }}}{\dot{E} X_{F, \text { total }, \text { RRRC }}}
\end{gathered}
$$

Since all the equipment's exergy consists of three parts (destruction, product, and fuel), their exergy equations are presented in Table 3 .

\subsection{Exergoeconomic Modeling}

In exergoeconomic (thermoeconomic) analysis, obtaining the cost of fuel and product difference is one of the most important goals. Therefore, all of each point's cost rates should be calculated by exergy, according to Eq. (17)[34].

$$
\dot{C}_{k}=c_{k}\left(\dot{E} X_{k}\right)
$$

The balance of cost equations determined as Eq. (18) by considering the inlet and outlet of each equipment and their investment cost rate[34]. Regarding the balance of exergoeconomic for cycles' equipment, product cost rate equals the sum of the fuel cost rate and investment cost rate (Eq. (19)) [34].

$$
\begin{aligned}
& \sum \dot{C}_{e}+\dot{C}_{w}=\dot{C}_{Q}+\sum \dot{C}_{i}+\dot{Z} \\
& \dot{C}_{P, k}=\dot{C}_{F, k}+\dot{Z}_{k}
\end{aligned}
$$

The investment cost rate of each equipment determined according to their capacity of work and heat transition; therefore, each equipment's sizes have an important impact on their investment cost rate. The cost of each equipment in refrigeration cycles is given in Eq. (20) to Eq. (27). 


\begin{tabular}{|c|c|}
\hline Parameter & Equation \\
\hline Entrainment ratio & $\mu=\frac{\dot{m_{s f}}}{\dot{m}_{p f}}$ \\
\hline Nozzle efficiency & $\eta_{n}=\frac{h_{p f i n}-h_{p f e x i}}{h_{p f i n}-h_{p f i s}}$ \\
\hline Primary flow outlet velocity & $u_{p f f e x i}=\sqrt{2 \eta_{n}\left(h_{p f, i n}-h_{p f i, i}\right)}$ \\
\hline The mixing chamber momentum conservation & $\dot{m}_{p f} u_{p f e x i}+\dot{m}_{s f} u_{s f e x i}=\left(\dot{m}_{s f}+\dot{m}_{p \rho}\right) u_{m f, i s}$ \\
\hline Secondary flow outlet velocity & $u_{s f, i,}=\sqrt{2 \times\left(h_{s f, i n}-h_{s f f e r i}\right)}$ \\
\hline Velocity of mixed flow & $u_{m f, i s}=\frac{u_{p f e x i}}{1+\mu}$ \\
\hline Mixing efficiency & $\eta_{m}=\frac{u_{m f}^{2}}{u_{m, i s}^{2}}$ \\
\hline Averaged velocity of mixed flow & $u_{m f}=\frac{u_{p f e r i x} \sqrt{\eta_{m}}}{1+\mu}$ \\
\hline Energy conversion in mixing chamber & $\dot{m}_{p f}\left(h_{p f f e x i}+\frac{u_{p f e x i}^{2}}{2}\right)+\dot{m}_{s f}\left(h_{s f f e x i}+\frac{u_{s f e x i}^{2}}{2}\right)=\left(\dot{m}_{s f}+\dot{m}_{p f}\right)\left(h_{m f}+\frac{u_{m f}^{2}}{2}\right)$ \\
\hline Mixed flow enthalpy & $h_{m f}=\frac{h_{p f i \text { in }}+\mu h_{\text {sferit }}}{1+\mu}-\frac{u_{m f}^{2}}{2}$ \\
\hline The actual enthalpy of mixed flow outlet & $h_{m f, e x i}=h_{m f}+\frac{h_{m f, e x i, i s}+h_{m f}}{\eta_{d}}$ \\
\hline Ejector performance & $\mu=\sqrt{\eta_{n} \eta_{m} \eta_{d}\left(h_{p f ; i n}-h_{p f, i s}\right) /\left(h_{m f, e x i, i s}-h_{m f}\right)}-1$ \\
\hline
\end{tabular}

Table 3. The equations used for modeling of the ejector [34].

\begin{tabular}{|c|c|c|c|}
\hline Component & Fuel exergy & Product exergy & Destruction exergy \\
\hline Compressor & $\dot{W}_{\text {Compressor }}$ & $\dot{E} X_{2}-\dot{E} X_{1}$ & $\dot{E} X_{F, \text { compressor }}-\dot{E} X_{P, \text { compressor }}$ \\
\hline Heat exchanger & $\dot{E} X_{2}-\dot{E} X_{3}$ & $\dot{E} X_{10}-\dot{E} X_{9}$ & $\dot{E} X_{F \text {,Heat Exchanger }}-\dot{E} X_{P, \text { Heat Exchanger }}$ \\
\hline Ejector & $\dot{E} X_{3}+\dot{E} X_{7}$ & $E X_{4}$ & $\dot{E} X_{F, E j e c t o r}-\dot{E} X_{P, E j e c t o r}$ \\
\hline Expansion valve & $\dot{E} X_{5}$ & $\dot{E} X_{6}$ & $\dot{E} X_{F, \text { Expansion value }}-\dot{E} X_{P, \text { Expansion value }}$ \\
\hline Evaporator & $\dot{E} X_{6}-\dot{E} X_{7}$ & $\dot{E} X_{15}-\dot{E} X_{14}$ & $E X_{F, \text { Evaportaro }}-E X_{P, \text { Evaporator }}$ \\
\hline Pump & $\dot{W}_{\text {Pump }}$ & $\dot{E} X_{9}-\dot{E} X_{8}$ & $\dot{E} X_{F, \text { Pump }}-\dot{E} X_{P, P_{\text {Pump }}}$ \\
\hline Turbine & $\dot{E} X_{10}-E X_{11}$ & $\dot{W}_{\text {Turbine }}$ & $\dot{E} X_{F, \text { Turbine }}-\dot{E} X_{P, T \text { urtine }}$ \\
\hline Condenser & $\dot{E} X_{11}-\dot{E} X_{8}$ & $\dot{E} X_{13}-\dot{E} X_{12}$ & $\dot{E} X_{F, \text { Condenser }}-\dot{E} X_{P, \text { Condenser }}$ \\
\hline
\end{tabular}

Heat exchanger[37]:

$Z_{\text {Heat exchanger }}^{C l}=130\left(\frac{A_{\text {Heat exchanger }}}{0.093}\right)$

Pump[38]:

$Z_{\text {Pump }}^{\text {CL }}=3450\left(\dot{W}_{\text {Pump }}\right)^{0.71}$

Turbine[37]:

$Z_{\text {Turbine }}^{C L}=4405\left(W_{\text {Turbine }}\right)^{0.7}$

Compressor[37]:

$Z_{\text {Compressor }}^{C L}=9624.2\left(\dot{W}_{\text {compressor }}\right)^{0.46}$

Expansion valve[39]:

$Z_{\text {Expansion valve }}^{C L}=114.5\left(m_{i}\right)$

Condenser[40]:

$Z_{\text {Condenser }}^{C l}=8000\left(\frac{A_{\text {Condenser }}}{100}\right)$

Evaporator[41]:

$$
Z_{\text {Evaporator }}^{C l}=309.15\left(A_{\text {Evaporator }}\right)+213.9
$$

Ejector[41]:

$$
Z_{\text {Ejector }}^{C l}=750\left(\dot{m}_{1}\right)\left(P_{4}^{0.75}\right)\left(\frac{T_{3}}{P_{3}}\right)^{0.05}
$$

A capital recovery factor is the ratio of a fixed annuity to the present value of receiving that annuity for a given length using an interest rate $\mathrm{I}$, the capital recovery factor is defined as Here, $\mathrm{i}$ is the interest rate (assumed to be $15 \%$ ) and $\mathrm{n}$ is the system life (assumed to be 20 years) [34, 42].

$$
\begin{aligned}
& C R F=\frac{i(1+i)^{n}}{(1+i)^{n}-1} \\
& \dot{Z}_{k}=\frac{Z_{k}^{C l} \cdot C R F \cdot \varphi}{t}
\end{aligned}
$$

By calculating the investment cost rate for each of the equipment and using them for every component used in $\mathrm{RC}$ and HRRC, the cost balance is presented in Table 4. In order to obtain the cost rate of each point, auxiliary equations for each of the equipment are given in this table. 
Table 4. The exergoeconomic balance for the overall system [34].

\begin{tabular}{|c|c|c|}
\hline Component & Exergoeconomic balance & Auxiliary equations \\
\hline Compressor & $\dot{Z}_{\text {Compressor }}+\dot{C}_{1}+\dot{C}_{\text {Compressor }}=\dot{C}_{2}$ & $c_{\mathrm{w}, \text { Compressor }}=0.015(\$ / \mathrm{MJ})$ [37] \\
\hline Heat exchanger & $\dot{Z}_{\text {Heat exchanger }}+\dot{C}_{2}+\dot{C}_{9}=\dot{C}_{3}+\dot{C}_{10}$ & $c_{9}=c_{10}$ \\
\hline Evaporator & $\dot{Z}_{\text {Evaporatar }}+\dot{C}_{6}+\dot{C}_{12}=\dot{C}_{13}+\dot{C}_{7}$ & $c_{9}=0$ \\
\hline Ejector & $\dot{Z}_{\text {Ejector }}+\dot{C}_{3}+\dot{C}_{7}=\dot{C}_{4}$ & - \\
\hline Separator & $\dot{Z}_{\text {Separator }}+\dot{C}_{4}=\dot{C}_{1}+\dot{C}_{5}$ & $c_{1}=c_{5}$ \\
\hline Condenser & $\dot{Z}_{\text {Condenser }}+\dot{C}_{16}+\dot{C}_{11}=\dot{C}_{8}+\dot{C}_{17}$ & $c_{8}=c_{11}$ \\
\hline Expansion valve & $\dot{Z}_{\text {Expansion value }}+\dot{C}_{5}=\dot{C}_{6}$ & - \\
\hline Pump & $\dot{Z}_{P_{u m p}}+\dot{C}_{8}+\dot{C}_{P_{u m p}}=\dot{C}_{9}$ & - \\
\hline Turbine & $\dot{Z}_{\text {Turbine }}+\dot{C}_{10}=\dot{C}_{11}+\dot{C}_{\text {Turbine }}$ & - \\
\hline
\end{tabular}

Destruction cost rate for each of the equipment is calculated by Eq. (30) [34].

$$
\dot{C}_{D, k}=c_{P, k} \dot{E} X_{D, k}
$$

The average partial cost increase in each unit of exergy between the equipment's fuel and product exergy is determined by relative cost deference. This parameter indicates that which of the equipment has the most cycle product cost comparing to other equipment. For this reason, the parameter is calculated according to Eq. (31)[34].

$$
r_{c}=\frac{c_{P, k}-c_{F, k}}{c_{F, k}}
$$

One of the exergoeconomic analysis's goals is to decrease the product cost rate. In order to achieve this goal, the exergoeconomic factor concept is fundamental, and it is calculated by Eq. (32) for each of the equipment[34].

$$
f_{c}=\frac{\dot{Z}_{k}}{\dot{Z}_{k+} \dot{C}_{D, k}+\dot{C}_{L, k}}
$$

\subsection{Advanced Exergy Modeling}

One of the exergy analysis goals is to decrease the destruction exergy of each equipment. This irreversibility can be decreased by improving exergy. Therefore, each equipment's destruction exergy is divided into exogenous $\left(E X_{D, k}^{E X}\right)$ and endogenous $\left(E X_{D, k}^{E N}\right)$. Therefore, each equipment's exogenous exergy destruction rate is due to the irreversibility of the other equipment to each other. Besides, the endogenous exergy destruction rate includes a condition, which that equipment should operate under a real condition, and others should operate under theoretical conditions. In this study, advanced exergy analysis was performed using the engineering approach (Figure 4). This method principally can be utilized for a component that chemical reactions take place, such as gasifier and combustion chamber[43]. $\dot{E}_{D \text { other }}$ is the sum of exergy destruction rates in system components other than that in component k. Regarding Figure 4, if the $\dot{E}_{D, \text { other }}$ converges to zero, the exogenous exergy destruction rate for $\mathrm{k}$ component converts zero, and the endogenous part is determined[44].

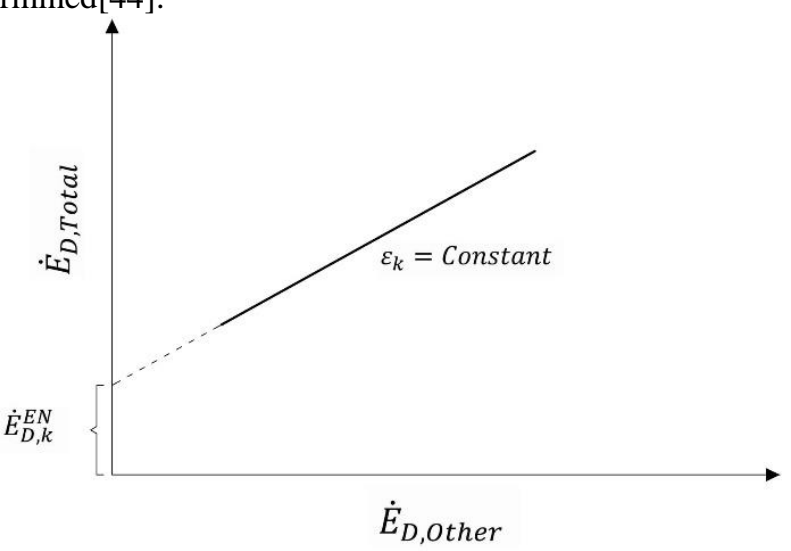

Figure 4. Determine the $\dot{E} X_{D, k}^{E N}$ by variation of $\dot{E}_{D, \text { other }}$ and $\dot{E}_{D, \text { Total }}[43]$.

With consider the operation of the cycle, the exergy destruction rate of each equipment can be divided into two separate parts include avoidable $\left(E X_{D, k}^{A V}\right)$ and unavoidable $\left(E X_{D, k}^{U N}\right)$ that the value of each of them can be calculated by Eq. (33) and Eq. (34) [45, 46].

$$
\begin{aligned}
& \dot{E} X_{D, k}=\dot{E} X_{D, k}^{E N}+\dot{E} X_{D, k}^{E X} \\
& \dot{E} X_{D, k}=\dot{E} X_{D, k}^{A V}+\dot{E} X_{D, k}^{U N}
\end{aligned}
$$

To determine the cause of the exergy destruction rate of each component can be combined and the values of endogenous unavoidable exergy destruction $\left(E X_{D, k}^{E N, U N}\right)$, exogenous unavoidable exergy destruction $\left(\dot{E} X_{D, k}^{E X, U N}\right)$, endogenous avoidable exergy destruction $\left(E X_{D, k}^{E N, A V}\right)$ and exogenous avoidable exergy destruction $\left(\dot{E} X_{D, k}^{E X, A V}\right)$ are presented in Eqs. (35) to (38)[45, 46].

$$
\begin{aligned}
& \dot{E} X_{D, k}^{A V}=\dot{E} X_{D, k}^{E X, A V}+\dot{E} X_{D, k}^{E N, A V} \\
& \dot{E} X_{D, k}^{U N}=\dot{E} X_{D, k}^{E X, U N}+\dot{E} X_{D, k}^{E N, U N} \\
& \dot{E} X_{D, k}^{E N}=\dot{E} X_{D, k}^{E N, A V}+\dot{E} X_{D, k}^{E N, U N}
\end{aligned}
$$




$$
\dot{E} X_{D, k}^{E X}=\dot{E} X_{D, k}^{E X, A V}+\dot{E} X_{D, k}^{E X, U N}
$$

\subsection{Exergoenvironmental Modeling}

Considering the environmental problems caused by thermodynamic cycles (as releasing the greenhouse gases that make the earth warmer), the importance of exergoenvironmental is considered more than before. The Assessments show that the exergoenvironmental follows two main parts, the first one is destruction exergy which caused by fuel exergy and product exergy difference and should be calculated for each of the equipment and its impacts should be assessed and the second part is Life Cycle Assessment(LCA) that caused by environmental impact. In order to assess the environmental impact of each point, the exergy and LCA analysis should be related[47].

In order to obtain the environmental impact of a process, LCA is used. Environmental impact is determined according to the cycle's operation time that consists of three parts: operating and maintenance (OM), generation, and disposal. Many different ways of assessing have been presented, and Eco - indicator 99 has the most suggestion and development for these impacts. Therefore, in this research Eco - indicator 99 is used. The obtained results of these impacts are shown as pts or mpts units[47].

The results are as the unit of mpts, and the system's operation is considered for 8760 hours and 20 years of useful life. The value of Eco - indicator 99 for each of the cycle's equipment in the process, material, and disposal parts are shown in Table 5[47].

In addition, the weight functions of all equipment are shown in Table 5. To calculate the weight of the compressor Eq. (39) and Eq. (40) are used[47].

$$
\begin{aligned}
& \dot{m}=\rho V A \\
& t=P . D \frac{F S}{2 \sigma}
\end{aligned}
$$

In these equations, $\dot{m}$ is the mass flow rate of fluid inside the compressor, $\rho$ is the fluid density, $V$ is velocity, and $A$ is the cross-section area. FS (Factor of safety) and $\sigma$ (rupture stress) are considered as Table 6 . Exergoenvironmental balance equations are defined according to Eq. (41)[48].

$$
\dot{B}_{P, k}=\dot{B}_{F, k}+\dot{Y}_{k}
$$

The relation of environmental impact and exergy is determined according to Eq. (42)[48].

$$
\begin{aligned}
& \dot{B}_{F, k}=b_{F, k}\left(\dot{E} X_{F, k}\right) \\
& b_{F} \dot{E} X_{F}=b_{P} \dot{E} X_{P}+\dot{Y}_{k}
\end{aligned}
$$

In this analysis, the component environmental impact is shown by $\dot{Y}$ that consisted of the process, material, and disposal parts according to LCA and followed Eq. (44).

$$
\dot{Y}^{\text {Total }}=\dot{Y}^{C O}+\dot{Y}^{O M}+\dot{Y}^{D I}
$$

Here $\dot{Y}^{C O}$ is related to construction environmental impact that consisted of manufacture and installation. $\dot{Y}^{O M}$ is operation and maintenance environmental impact, and $\dot{Y}^{I I}$ is related to disposal environmental impact[48]. Eq. (45) presents the rate of environment destruction exergy of each equipment.

$$
\dot{B}_{D, k}=b_{F, k}\left(\dot{E} X_{D, k}\right)
$$

Equipment's information with their weight functions is shown in Table 5 and Table 6 using Cavalcanti's analysis. The balance equations of all the equipment's exergoenvironmental with auxiliary equations are shown in Table 7 in order to determine the environment exergy rate of all points. By using the relative difference of the environmental impacts, it can be recognized all the equipment that has the most potential to decrease the environmental impact, and it is calculated by Eq. (46).

$$
r_{b, k}=\frac{b_{P, k}-b_{F, k}}{b_{F, k}}
$$

The total environmental impact for each of the equipment is determined by Eq. (47).

\begin{tabular}{|c|c|c|c|c|}
\hline Component & Materials composition Eco'99 (mpts/kg) & $\begin{array}{l}\text { Material } \\
\text { (mpts/kg) }\end{array}$ & $\begin{array}{l}\text { Process } \\
\text { (mpts } / \mathrm{kg})\end{array}$ & $\begin{array}{l}\text { Disposal } \\
\text { (mpts/kg) }\end{array}$ \\
\hline compressor & $\begin{array}{l}\text { steel } 33.33 \% 86 \text { Steel low alloy } 44.5 \% 110 \text { Cast iron } \\
22.22 \% 240\end{array}$ & 130 & 11.7 & -70 \\
\hline Evaporator & Steel $100 \% 86$ & 86 & 12.1 & -70 \\
\hline Condenser & Steel $100 \% 86$ & 86 & 12.1 & -70 \\
\hline Pump & Cast iron $65 \% 240$ Steel $35 \% 86$ & 186 & 16.5 & -70 \\
\hline Steam turbine & Steel 25\% 86 Steel high alloy $75 \% 910$ & 704 & 12.1 & -70 \\
\hline Heat recovery & Steel $26 \% 86$ Steel high alloy $74 \%$ & 696 & 12.1 & -70 \\
\hline
\end{tabular}

$$
\dot{B}_{\text {Total }}=\dot{B}_{D}+\dot{Y}^{\text {Total }}
$$

Exergoenvironmental factor defined by Eq. (48), and according to that, the equipment with a higher exergoenvironmental factor can be recognized[48].

$$
f_{b, k}=\frac{\dot{Y}_{k}^{\text {Total }}}{\dot{B}_{D}+\dot{Y}^{\text {Total }}}
$$

Table 5. Information of component-related environmental impact in LCA[47]. 


\begin{tabular}{|c|c|c|}
\hline Component & \multicolumn{2}{|c|}{ Weight function (ton) } \\
\hline Compressor & \multicolumn{2}{|c|}{ Eqs. (39) and (40), $\mathrm{FS}=2, V_{\text {Axial }}=15 \mathrm{~m} / \mathrm{s}$} \\
\hline Evaporator & \multicolumn{2}{|c|}{$w_{\text {Evaporator }}=13.9\left(\dot{Q}^{0.68}\right), \mathrm{MW}$} \\
\hline Condenser & \multicolumn{2}{|c|}{$w_{\text {Condenser }}=0.073\left(\dot{Q}^{0.99}\right), \mathrm{MW}$} \\
\hline Pump & \multicolumn{2}{|c|}{$w_{P_{u m p}}=0.125 \cdot \ln (\dot{W})-0.041, \mathrm{~kW}$} \\
\hline Steam turbine & \multicolumn{2}{|c|}{$w_{\text {Turbine }}=4.9\left(\dot{W}^{0.73}\right), \mathrm{MW}$} \\
\hline Heat recovery & \multicolumn{2}{|c|}{$w_{\text {Heat recovery }}=8.42\left(\dot{Q}^{0.87}\right), \mathrm{MW}$} \\
\hline \multicolumn{3}{|c|}{ Table 7. The Exergoenvironmental balance for the overall system [49]. } \\
\hline Component & Exergoenvironmental balance & Auxiliary equations \\
\hline Compressor & $\dot{Y}_{\text {Compressor }}+\dot{B}_{1}+\dot{B}_{\text {Compressor }}=\dot{B}_{2}$ & $b_{\text {compressor }}=6.206(\mathrm{mpts} / \mathrm{MJ})$ \\
\hline Heat exchanger & $\dot{Y}_{\text {Heat exchanger }}+\dot{B}_{2}+\dot{B}_{9}=\dot{B}_{3}+\dot{B}_{10}$ & $b_{9}=b_{10}$ \\
\hline Evaporator & $\dot{Y}_{\text {Evaporator }}+\dot{B}_{6}+\dot{B}_{12}=\dot{B}_{13}+\dot{B}_{7}$ & $b_{12}=0$ \\
\hline Ejector & $\dot{Y}_{\text {Ejector }}+\dot{B}_{3}+\dot{B}_{7}=\dot{B}_{4}$ & - \\
\hline Separator & $\dot{Y}_{\text {Separator }}+\dot{B}_{4}=\dot{B}_{1}+\dot{B}_{5}$ & $b_{1}=b_{5}$ \\
\hline Condenser & $\dot{Y}_{\text {Condenser }}+\dot{B}_{16}+\dot{B}_{11}=\dot{B}_{8}+\dot{B}_{17}$ & $b_{8}=b_{11}$ \\
\hline Expansion valve & $\dot{Y}_{\text {Expansion valve }}+\dot{B}_{5}=\dot{B}_{6}$ & - \\
\hline Pump & $\dot{Y}_{P \text { Pump }}+\dot{B}_{8}+\dot{B}_{P_{\text {Pump }}}=\dot{B}_{9}$ & $b_{\text {compressor }}=6.206(\mathrm{mpts} / \mathrm{MJ})$ \\
\hline Turbine & $\dot{Y}_{\text {Turbine }}+\dot{B}_{10}=\dot{B}_{11}+\dot{B}_{\text {Turbine }}$ & - \\
\hline
\end{tabular}

The computational process performed in this paper for RC and HRRC cycles is shown in Figure 5.

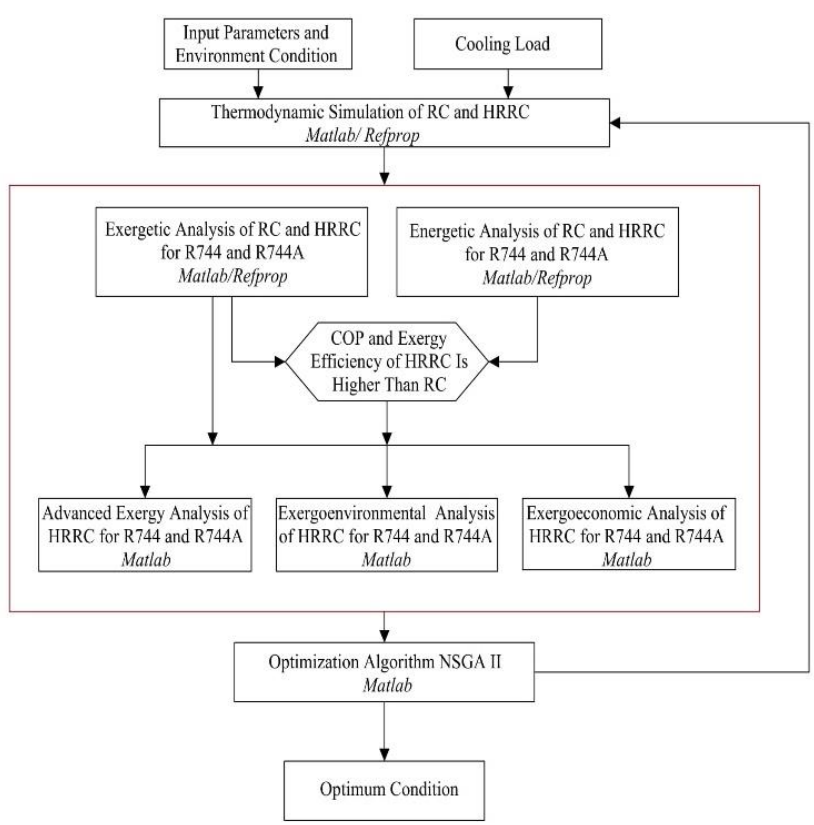

Figure 5. The flowchart of the computational process.

\section{Results and Discussion}

In this part, 4E (energy, exergy, exergoeconomic, and exergoenvironmental) and advance exergy analysis are evaluated. The selected input parameters for $\mathrm{RC}$ and HRRC are the same with working fluids R744 and R744A. In addition, the cooling capacity of both cycles considered as $100 \mathrm{~kW}$. The thermodynamic properties of both cycles using working fluids R744 and R744A are given in Table 8 and Table 9. According to the presented results in Table 7 , the most temperature and pressure are for the compressor's outlet, and according to Table 8 , the compressor has more outlet temperature while using R744A.

\subsection{The Results of Energy and Exergy Analysis}

The results of the energy analysis, calculated by Eqs.(8) and (9), indicate that the COP for RC and HRRC with R744 are about 2.51 and 2.82 and with R744A are about 2.26 and 2.74, respectively. Exergy analysis results of R744 and R744A cycles are given in Tables 10 and 11 . The main portion of the fuel exergy rate in the heat exchanger is disappeared and utilizing heat recovery instead of heat exchanger leads to a dramatic reduction in the exergy destruction rate for both working fluids. The amount of exergy destruction has been decreased by about $90 \%$ with both refrigerants. 
Table 8. Thermodynamic properties of each state point of the RC and HRRC for R744.

\begin{tabular}{|c|c|c|c|c|c|c|c|c|c|}
\hline $\begin{array}{l}\text { State } \\
\text { point }\end{array}$ & Fluid & $\begin{array}{c}P \\
(\mathrm{kPa})\end{array}$ & $\begin{array}{c}T \\
(\mathrm{~K})\end{array}$ & $\begin{array}{c}h \\
(\mathrm{~kJ} / \mathrm{kg})\end{array}$ & $\begin{array}{c}s \\
(\mathrm{~kJ} / \mathrm{kg} \cdot \mathrm{K})\end{array}$ & $\begin{array}{c}\dot{m} \\
(\mathrm{~kg} / \mathrm{s})\end{array}$ & $\begin{array}{c}\dot{E X} \\
(\mathrm{~kW})\end{array}$ & $\begin{array}{c}\dot{C} \\
(\$ / h)\end{array}$ & $\begin{array}{c}\dot{B} \\
(\mathrm{mpts} / \mathrm{h})\end{array}$ \\
\hline 1 & R744 & 4450 & 282.68 & 423.37 & 1.78 & 0.96 & 192.49 & 4.055 & 40.911 \\
\hline 2 & R744 & 9750 & 348.29 & 464.51 & 1.82 & 0.96 & 221.76 & 7.201 & 929.875 \\
\hline 3 & R744 & 9750 & 313.15 & 317.29 & 1.37 & 0.96 & 209.86 & 6.814 & 879.921 \\
\hline 4 & R744 & 4450 & 282.68 & 353.97 & 1.54 & 1.45 & 296.2 & 8.846 & 900.415 \\
\hline 5 & R744 & 4450 & 282.68 & 224.45 & 1.084 & 0.49 & 103.53 & 2.181 & 22.008 \\
\hline 6 & R744 & 3969.46 & 278.15 & 224.45 & 1.086 & 0.49 & 103.201 & 2.182 & 22.008 \\
\hline 7 & R744 & 3969.46 & 278.15 & 427.48 & 1.81 & 0.49 & 96.102 & 2.032 & 20.493 \\
\hline 8 & R744 & 7213.68 & 303.15 & 304.55 & 1.343 & 0.98 & 209.82 & 11.177 & 971.590 \\
\hline 9 & R744 & 9750 & 311.89 & 309.67 & 1.346 & 0.98 & 213.88 & 11.663 & 1083.8 \\
\hline 10 & R744 & 9750 & 343.06 & 453.88 & 1.79 & 0.98 & 224.94 & 12.267 & 1139.9 \\
\hline 11 & R744 & 7213.68 & 320.21 & 444.4 & 1.8 & 0.98 & 213.48 & 11.372 & 988.561 \\
\hline 12 & Water & 101 & 290.15 & 71.45 & 0.25 & 2.5 & 1.101 & 0 & 0 \\
\hline 13 & Water & 101 & 280.65 & 31.65 & 0.11 & 2.5 & 5.502 & 0.267 & 2.024 \\
\hline 14 & Water & 101 & 295.15 & 91.74 & 0.32 & 2.5 & 0.15 & 0 & 0 \\
\hline 15 & Water & 101 & 308.11 & 146.56 & 0.504 & 2.5 & 1.75 & 0.236 & 16.972 \\
\hline 16 & Water & 101 & 298.15 & 104.29 & 0.36 & 2.5 & 0 & 0 & 0 \\
\hline 17 & Water & 101 & 311.52 & 160.82 & 0.55 & 2.5 & 3.11 & 0.426 & 56.107 \\
\hline
\end{tabular}

Table 9. Thermodynamic properties of each state point of the RC and HRRC for R744A.

\begin{tabular}{|c|c|c|c|c|c|c|c|c|c|}
\hline $\begin{array}{l}\text { State } \\
\text { point }\end{array}$ & Fluid & $\begin{array}{c}P \\
(\mathrm{kPa})\end{array}$ & $\begin{array}{c}T \\
(\mathrm{~K})\end{array}$ & $\begin{array}{c}h \\
(\mathrm{~kJ} / \mathrm{kg})\end{array}$ & $\begin{array}{c}s \\
(\mathrm{~kJ} / \mathrm{kg} . \mathrm{K})\end{array}$ & $\begin{array}{c}\dot{m} \\
(\mathrm{~kg} / \mathrm{s})\end{array}$ & $\begin{array}{c}\dot{E X} \\
(\mathrm{~kW})\end{array}$ & $\begin{array}{c}\dot{C} \\
(\$ / \mathrm{h})\end{array}$ & $\begin{array}{c}\dot{B} \\
(\mathrm{mpts} / \mathrm{h})\end{array}$ \\
\hline 1 & R744A & 4150 & 284.67 & 390.44 & 1.509 & 0.96 & 188.36 & 4.106 & 42.748 \\
\hline 2 & R744A & 9750 & 358.12 & 438.34 & 1.548 & 0.96 & 221.31 & 7.554 & 1034.9 \\
\hline 3 & R744A & 9750 & 313.15 & 260.73 & 1.011 & 0.96 & 204.54 & 6.981 & 956.336 \\
\hline 4 & R744A & 4150 & 284.67 & 321.96 & 1.262 & 1.45 & 289.29 & 9.022 & 977.577 \\
\hline 5 & R744A & 4150 & 284.67 & 192.31 & 0.806 & 0.49 & 100.73 & 2.196 & 22.867 \\
\hline 6 & R744A & 3541.6 & 278.15 & 192.32 & 0.809 & 0.49 & 100.27 & 2.198 & 22.867 \\
\hline 7 & R744A & 3541.6 & 278.15 & 396.28 & 1.543 & 0.49 & 93.14 & 2.041 & 21.240 \\
\hline 8 & R744A & 6307.5 & 303.15 & 246.708 & 0.981 & 0.98 & 203.61 & 9.690 & 1007.1 \\
\hline 9 & R744A & 9750 & 310.89 & 252.81 & 0.985 & 0.98 & 208.45 & 10.256 & 1140.8 \\
\hline 10 & R744A & 9750 & 352.27 & 426.79 & 1.515 & 0.98 & 224.108 & 11.028 & 1226.7 \\
\hline 11 & R744A & 6307.5 & 318.602 & 412.91 & 1.526 & 0.98 & 207.32 & 9.866 & 1025.4 \\
\hline 12 & Water & 101 & 290.15 & 71.45 & 0.253 & 2.5 & 1.101 & 0 & 0 \\
\hline 13 & Water & 101 & 280.61 & 31.47 & 0.113 & 2.5 & 5.53 & 0.275 & 2.138 \\
\hline 14 & Water & 101 & 295.15 & 91.74 & 0.322 & 2.5 & 0.15 & 0 & 0 \\
\hline 15 & Water & 101 & 310.58 & 156.9 & 0.538 & 2.5 & 2.701 & 0.228 & 18.349 \\
\hline 16 & Water & 101 & 298.15 & 104.29 & 0.365 & 2.5 & 0 & 0 & 0 \\
\hline 17 & Water & 101 & 314.31 & 172.49 & 0.587 & 2.5 & 4.504 & 0.616 & 85.804 \\
\hline
\end{tabular}

Table 10. Results of exergy analysis for $R 744$.

\begin{tabular}{cccc}
\hline Component & $E X_{F}(\mathrm{~kW})$ & $\dot{E} X_{P}(\mathrm{~kW})$ & $E X_{D}(\mathrm{~kW})$ \\
\hline Compressor & 39.488 & 29.262 & 10.226 \\
Ejector & 305.963 & 296.207 & 9.756 \\
Evaporator & 7.099 & 4.401 & 2.698 \\
Heat exchanger & 11.899 & 3.112 & 8.787 \\
Expansion Valve & 103.537 & 103.201 & 0.336 \\
Heat recovery & 11.899 & 11.059 & 0.84 \\
Condenser & 3.658 & 1.594 & 2.064 \\
Pump & 5.017 & 4.058 & 0.959 \\
Turbine & 11.458 & 9.293 & 2.165 \\
\hline
\end{tabular}

Table 11. Results of exergy analysis for R744A.

\begin{tabular}{cccc}
\hline Component & $E X_{F}(\mathrm{~kW})$ & $E X_{P}(\mathrm{~kW})$ & $E X_{D}(\mathrm{~kW})$ \\
\hline Compressor & 44.063 & 32.954 & 11.109 \\
Ejector & 297.681 & 289.291 & 8.39 \\
Evaporator & 7.132 & 4.429 & 2.703 \\
Heat exchanger & 16.777 & 4.504 & 12.273 \\
Expansion valve & 100.733 & 100.272 & 0.461 \\
Heat recovery & 16.777 & 15.655 & 1.122 \\
Condenser & 3.7009 & 2.542 & 1.1589 \\
Pump & 5.981 & 4.834 & 1.147 \\
Turbine & 16.788 & 13.6001 & 3.1879 \\
\hline
\end{tabular}

The exergy efficiencies of RC and HRRC for R744 are $11.14 \%$ and $30.77 \%$, and for R744A are about $10.05 \%$ and $36.02 \%$. As has been predicted, using the outlet heat can increase the operation of the refrigeration cycle. Usage of the internal Rankine cycle for R744 increases the COP about $12 \%$ and exergy efficiency $276 \%$ and R744A makes an increase of about $21 \%$ in COP and $360 \%$ in exergy efficiency. According to the obtained results that the HRRC is favorable in terms of energy and exergy, other analyses include exergoeconomic, exergoenvironmental, and advance exergy analysis are done for HRRC cycle.

\subsection{The Results of Exergoeconomic Analysis}

The results of exergoeconomic analysis for HRRC with R744 and R744A are given in Tables 12 and 13. All the equipment's investment cost rate has been calculated according to their capacity, and the highest amount for both cycles is related to the compressor.

The obtained values of relative cost deference indicate that condenser in HRRC-R744 has the highest amount that can be caused by the high-cost rate of investment or destruction cost rate of that equipment; consequently, the exergoeconomic factor should be considered to determine. The high-cost rate of the condenser is due to the high cost of the exergy destruction rate. In HRRCR744A, the highest amount of relative cost deference belongs to the evaporator while the heat recovery has the highest amount of exergoeconomic factor. 


\subsection{The Results of Advanced Exergy Analysis}

Tables 14 and 15 illustrate advanced exergy analysis results for HRRC with R744 and R744A working fluids. These values for each of the equipment are given separately. Exergy destruction improvement potential is determined according to avoidable exergy destruction rate. Avoidable exergy destruction rate is lower than unavoidable exergy destruction in all of the equipment. Considering the fact that the ejector and the compressor have the highest destruction ratio and consist of an extensive amount of the endogenous exergy destruction rate, their operation can be improved because other components have a lower influence on them. Generally, the exogenous rates for different components are low.
Figs. 6 and 7 illustrate the different parts of the destruction rate for refrigeration cycles with different working fluids. Figs. 6(a) and 7(a) show that the destruction exergy of the HRRC for both working fluids is mainly due to the equipment's improper functioning, and the destructive effect of the components is minimal. In contrast, according to Figs. 6(b) and 7(b), the effect of unavoidable is greater than avoidable. Most of the exergy improvement effects are related to avoidable endogenous exergy destruction that has relatively good values. It is recommended that the cycle's design is to minimize the amount of unavoidable exogenous exergy destruction.

Table 12. The exergoeconomic results of the HRRC-R744 for each component.

\begin{tabular}{|c|c|c|c|c|c|c|c|c|c|}
\hline Component & $\begin{array}{l}c_{F} \\
(\$ / \mathrm{MJ})\end{array}$ & $\begin{array}{l}c_{P} \\
(\$ / \mathrm{MJ})\end{array}$ & $\begin{array}{l}\dot{C}_{F} \\
(\$ / \mathrm{h})\end{array}$ & $\begin{array}{l}\dot{C}_{P} \\
(\$ / \mathrm{h})\end{array}$ & $\begin{array}{l}\dot{C}_{D} \\
(\$ / \mathrm{h})\end{array}$ & $\begin{array}{l}\dot{Z} \\
(\$ / h)\end{array}$ & $\begin{aligned} \dot{C}_{D}+\dot{Z} \\
\quad(\$ / \mathrm{h})\end{aligned}$ & $\begin{array}{c}r \\
(\%)\end{array}$ & $\underset{(\%)}{f}$ \\
\hline Compressor & 0.015 & 0.029 & 2.135 & 3.145 & 1.099 & 1.010 & 2.109 & 98.75 & 47.88 \\
\hline Condenser & 0.014 & 0.041 & 0.195 & 0.236 & 0.305 & 0.041 & $0 . .346$ & 177.60 & 11.83 \\
\hline Ejector & 0.008 & 0.008 & 8.846 & 8.846 & 0.292 & 0 & 0.292 & 3.30 & 0.007 \\
\hline Evaporator & 0.005 & 0.016 & 0.150 & 0.267 & 0.164 & 0.117 & 0.281 & 187.25 & 41.71 \\
\hline $\begin{array}{l}\text { Heat } \\
\text { recovery }\end{array}$ & 0.009 & 0.015 & 0.386 & 0.603 & 0.045 & 0.216 & 0.262 & 67.93 & 82.54 \\
\hline Pump & 0.015 & 0.033 & 0.270 & 0.486 & 0.114 & 0.215 & 0.329 & 121.77 & 65.19 \\
\hline Separator & 0.005 & 0.005 & 6.236 & 6.236 & 0.003 & 0 & 0.003 & 0 & 0 \\
\hline Turbine & 0.021 & 0.038 & 0.894 & 1.300 & 0.303 & 0.405 & 0.708 & 79.21 & 57.24 \\
\hline $\begin{array}{l}\text { Expansion } \\
\text { valve }\end{array}$ & 0.005 & 0.005 & 2.181 & 2.182 & 0.007 & 0.001 & 0.008 & 0.37 & 13.38 \\
\hline
\end{tabular}

Table 13. The exergoeconomic results of the HRRC-R744A for each component.

\begin{tabular}{|c|c|c|c|c|c|c|c|c|c|}
\hline Component & $\begin{array}{l}c_{F} \\
(\$ / \mathrm{MJ})\end{array}$ & $\begin{array}{l}c_{P} \\
(\$ / \mathrm{MJ})\end{array}$ & $\begin{array}{l}\dot{C}_{F} \\
(\$ / \mathrm{h})\end{array}$ & $\begin{array}{l}\dot{C}_{P} \\
(\$ / \mathrm{h})\end{array}$ & $\begin{array}{l}\dot{C}_{D} \\
(\$ / \mathrm{h})\end{array}$ & $\begin{array}{l}\dot{Z} \\
(\$ / h)\end{array}$ & $\begin{array}{c}\dot{C}_{D}+\dot{Z} \\
(\$ / \mathrm{h})\end{array}$ & $\begin{array}{c}r \\
(\%)\end{array}$ & $\begin{array}{c}f \\
(\%)\end{array}$ \\
\hline Compressor & 0.015 & 0.029 & 2.385 & 3.447 & 1.162 & 1.062 & 2.224 & 93.27 & 47.76 \\
\hline Condenser & 0.013 & 0.024 & 0.176 & 0.228 & 0.104 & 0.051 & 0.155 & 88.20 & 33.17 \\
\hline Ejector & 0.008 & 0.008 & 9.022 & 9.022 & 0.263 & 0 & 0.263 & 2.92 & 0.008 \\
\hline Evaporator & 0.006 & 0.017 & 0.156 & 0.275 & 0.167 & 0.118 & 0.286 & 183.06 & 41.43 \\
\hline $\begin{array}{l}\text { Heat } \\
\text { recovery }\end{array}$ & 0.009 & 0.013 & 0.573 & 0.771 & 0.055 & 0.198 & 0.253 & 44.16 & 78.16 \\
\hline Pump & 0.015 & 0.032 & 0.323 & 0.566 & 0.134 & 0.243 & 0.378 & 117.07 & 64.43 \\
\hline Separator & 0.006 & 0.006 & 6.303 & 6.303 & 0.004 & 0 & 0.004 & 0 & 0 \\
\hline Turbine & 0.019 & 0.034 & 1.161 & 1.691 & 0.396 & 0.529 & 0.926 & 79.72 & 57.19 \\
\hline $\begin{array}{l}\text { Expansion } \\
\text { valve }\end{array}$ & 0.006 & 0.006 & 2.196 & 2.198 & 0.010 & 0.001 & 0.011 & 0.503 & 9.79 \\
\hline
\end{tabular}

Table 14. The advanced exergy results of the HRRC-R744 for each component.

\begin{tabular}{|c|c|c|c|c|c|c|c|c|c|}
\hline Component & $\begin{array}{r}E X_{D} \\
(\mathrm{~kW})\end{array}$ & $\begin{array}{c}\dot{E X_{D}^{A V}} \\
(\mathrm{~kW})\end{array}$ & $\begin{array}{c}E X_{D}^{U N} \\
(\mathrm{~kW})\end{array}$ & $\begin{array}{c}E X_{D}^{E N} \\
(\mathrm{~kW})\end{array}$ & $\begin{array}{c}E X_{D}^{E X} \\
(\mathrm{~kW})\end{array}$ & $\begin{array}{c}E X_{D}^{A V, E N} \\
(\mathrm{~kW})\end{array}$ & $\begin{array}{c}E X_{D}^{A V, E X} \\
(\mathrm{~kW})\end{array}$ & $\begin{array}{c}\dot{E} X_{D}^{U N, E N} \\
(\mathrm{~kW})\end{array}$ & $\begin{array}{c}E X_{D}^{U N, E X} \\
(\mathrm{~kW})\end{array}$ \\
\hline Compressor & 10.226 & 2.057 & 8.169 & 7.702 & 2.524 & 1.550 & 0.508 & 6.153 & 2.016 \\
\hline Ejector & 9.756 & 0.986 & 8.770 & 8.207 & 1.549 & 0.830 & 0.157 & 7.377 & 1.393 \\
\hline Evaporator & 2.698 & 0.114 & 2.584 & 2.596 & 0.102 & 0.110 & 0.004 & 2.486 & 0.097 \\
\hline Separator & 0.171 & 0.003 & 0.168 & 0.163 & 0.008 & 0.003 & 0.000 & 0.160 & 0.008 \\
\hline Expansion valve & 0.336 & 0.004 & 0.332 & 0.326 & 0.010 & 0.004 & 0.000 & 0.323 & 0.010 \\
\hline Heat recovery & 0.84 & 0.380 & 0.460 & 0.498 & 0.342 & 0.225 & 0.155 & 0.273 & 0.187 \\
\hline Condenser & 2.064 & 0.149 & 1.915 & 1.943 & 0.121 & 0.140 & 0.009 & 1.802 & 0.113 \\
\hline Pump & 0.959 & 0.136 & 0.823 & 0.855 & 0.104 & 0.122 & 0.015 & 0.733 & 0.089 \\
\hline Turbine & 2.165 & 0.330 & 1.835 & 1.848 & 0.317 & 0.282 & 0.048 & 1.566 & 0.269 \\
\hline
\end{tabular}

Table 15. The advanced exergy results of the HRRC-R744A for each component.

\begin{tabular}{|c|c|c|c|c|c|c|c|c|c|}
\hline Component & $\begin{array}{r}E X_{D} \\
(\mathrm{~kW})\end{array}$ & $\begin{aligned} & E X_{D}^{A V} \\
&(\mathrm{~kW})\end{aligned}$ & $\begin{array}{c}E X_{D}^{U N} \\
(\mathrm{~kW})\end{array}$ & $\begin{array}{c}E X_{D}^{E N} \\
(\mathrm{~kW})\end{array}$ & $\begin{array}{c}E X_{D}^{E X} \\
(\mathrm{~kW})\end{array}$ & $\begin{array}{c}\dot{E} X_{D}^{A V, E N} \\
(\mathrm{~kW})\end{array}$ & $\begin{array}{c}E \dot{E} X_{D}^{A V, E X} \\
(\mathrm{~kW})\end{array}$ & $\begin{array}{c}\dot{E} X_{D}^{U N, E N} \\
(\mathrm{~kW})\end{array}$ & $\begin{array}{c}E X_{D}^{U N, E X} \\
(\mathrm{~kW})\end{array}$ \\
\hline Compressor & 11.109 & 2.235 & 8.874 & 8.367 & 2.742 & 1.684 & 0.552 & 6.684 & 2.190 \\
\hline Ejector & 8.39 & 0.848 & 7.542 & 7.058 & 1.332 & 0.714 & 0.135 & 6.344 & 1.198 \\
\hline Evaporator & 2.703 & 0.114 & 2.589 & 2.601 & 0.102 & 0.110 & 0.004 & 2.491 & 0.098 \\
\hline Separator & 0.193 & 0.003 & 0.190 & 0.184 & 0.009 & 0.003 & 0.000 & 0.181 & 0.009 \\
\hline $\begin{array}{l}\text { Expansion } \\
\text { valve }\end{array}$ & 0.461 & 0.005 & 0.456 & 0.448 & 0.013 & 0.005 & 0.000 & 0.443 & 0.013 \\
\hline Heat recovery & 1.122 & 0.098 & 1.024 & 1.036 & 0.086 & 0.090 & 0.007 & 0.946 & 0.078 \\
\hline Condenser & 1.1589 & 0.132 & 1.027 & 1.042 & 0.117 & 0.118 & 0.013 & 0.924 & 0.103 \\
\hline Pump & 1.147 & 0.163 & 0.984 & 1.022 & 0.125 & 0.145 & 0.018 & 0.877 & 0.107 \\
\hline Turbine & 3.1879 & 0.486 & 2.701 & 2.721 & 0.467 & 0.415 & 0.071 & 2.306 & 0.395 \\
\hline
\end{tabular}




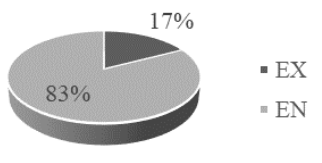

(a)

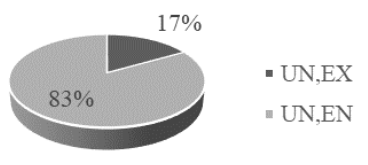

(c)

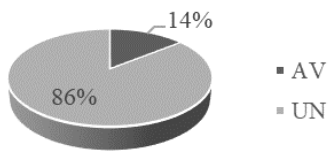

(b)

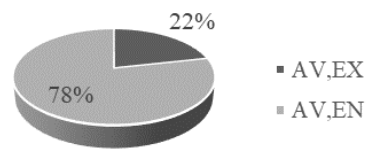

(d)

Figure 6. Separation of different sections of exergy destruction rate of HRRC-R744.

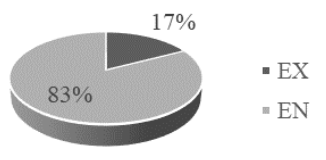

(a)

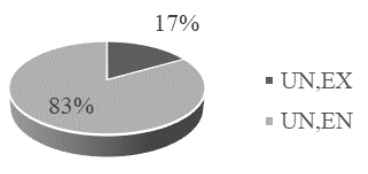

(c)

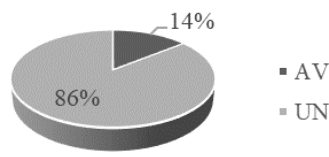

(b)

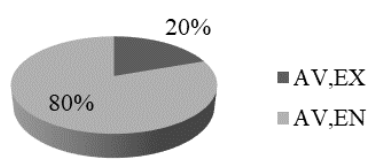

(d)

Figure 7. Separation of different sections of exergy destruction rate of HRRC-R744A.

\subsection{The Results of Exergoenvironmental Analysis}

The results of exergoenvironmental analysis for HRRC with both working fluids are given in Tables 16 and 17. The highest environmental impacts for both working fluids belong to the compressor and then to the turbine. It was expected that these components have an important position in the environment because of their high destruction exergy. In addition, the expansion valve and separator have the lowest environmental impacts.
Environmental impacts of consumed electricity in the compressor and the pump equal 6.206(mpts/MJ) [49], according to Table 7 . The highest values of environmental impacts difference relative for R744 and R744A belongs to the condenser and the evaporator. These components have a high potential in order to decrease environmental impacts.

Table 16. The exergoenvironmental results of the HRRC-R744 for each component.

\begin{tabular}{cccccccccc}
\hline Component & $\begin{array}{c}b_{F} \\
(\mathrm{mpts} / \mathrm{MJ})\end{array}$ & $\begin{array}{c}b_{P} \\
(\mathrm{mpts} / \mathrm{MJ})\end{array}$ & $\begin{array}{c}\dot{B}_{F} \\
(\mathrm{mpts} / \mathrm{h})\end{array}$ & $\begin{array}{c}\dot{B}_{P} \\
(\mathrm{mpts} / \mathrm{h}\end{array}$ & $\begin{array}{c}\dot{B}_{D} \\
(\mathrm{mpts} / \mathrm{h})\end{array}$ & $\begin{array}{c}\dot{Y} \\
(\mathrm{mpts} / \mathrm{h})\end{array}$ & $\begin{array}{c}\dot{B}_{D}+\dot{Y} \\
(\mathrm{mpts} / \mathrm{h})\end{array}$ & $\begin{array}{c}r_{B} \\
(\%)\end{array}$ & $\begin{array}{c}f_{B} \\
(\%)\end{array}$ \\
\hline Compressor & 6.206 & 8.424 & 883.66 & 888.96 & 228.80 & 5.303 & 234.112 & 35.75 & 2.27 \\
Condenser & 1.286 & 2.950 & 16.970 & 16.972 & 9.572 & 0.001 & 9.574 & 129.4 & 0.01 \\
Ejector & 0.817 & 0.844 & 900.41 & 900.41 & 28.811 & 0 & 28.811 & 3.31 & 0 \\
Evaporator & 0.059 & 0.127 & 1.514 & 2.024 & 0.575 & 0.509 & 1.084 & 115.5 & 46.9 \\
Heat recovery & 1.164 & 1.407 & 49.953 & 56.107 & 3.527 & 6.154 & 9.681 & 20.85 & 63.5 \\
Pump & 6.206 & 7.681 & 112.08 & 112.22 & 21.424 & 0.133 & 21.558 & 23.78 & 0.62 \\
Separator & 0.059 & 0.059 & 62.920 & 62.920 & 0.521 & 0 & 0.521 & 0 & 0 \\
Turbine & 3.666 & 4.540 & 151.35 & 152.01 & 28.604 & 0.653 & 29.257 & 23.83 & 2.23 \\
Expansion & 0.059 & 0.059 & 22.008 & 22.008 & 0.070 & 0 & 0.070 & 0.32 & 0 \\
valve & & & & & & & & \\
\hline
\end{tabular}


Table 17. The exergoenvironmental results of the HRRC-R744A for each component.

\begin{tabular}{cccccccccc}
\hline Component & $\begin{array}{c}b_{F} \\
(\mathrm{mpts} / \mathrm{MJ})\end{array}$ & $\begin{array}{c}b_{P} \\
(\mathrm{mpts} / \mathrm{MJ})\end{array}$ & $\begin{array}{c}\dot{B}_{F} \\
(\mathrm{mpts} / \mathrm{h})\end{array}$ & $\begin{array}{c}\dot{B}_{P} \\
(\mathrm{mpts} / \mathrm{h}\end{array}$ & $\begin{array}{c}\dot{B}_{D} \\
(\mathrm{mpts} / \mathrm{h})\end{array}$ & $\begin{array}{c}\dot{Y} \\
(\mathrm{mpts} / \mathrm{h})\end{array}$ & $\begin{array}{c}\dot{B}_{D}+\dot{Y} \\
(\mathrm{mpts} / \mathrm{h})\end{array}$ & $\begin{array}{c}r_{B} \\
(\%)\end{array}$ & $\begin{array}{c}f_{B} \\
(\%)\end{array}$ \\
\hline Compressor & 6.206 & 8.342 & 986.76 & 992.14 & 248.738 & 5.379 & 254.117 & 34.4 & 2.12 \\
Condenser & 1.373 & 2.0006 & 18.347 & 18.349 & 5.746 & 0.002 & 5.748 & 45.6 & 0.03 \\
Ejector & 0.912 & 0.938 & 977.57 & 977.57 & 27.736 & 0 & 27.736 & 2.92 & 0 \\
Evaporator & 0.063 & 0.134 & 1.627 & 2.138 & 0.616 & 0.511 & 1.127 & 111 & 45.3 \\
Heat recovery & 1.298 & 1.520 & 78.558 & 85.804 & 5.255 & 7.246 & 12.501 & 17.0 & 57.9 \\
Pump & 6.206 & 7.687 & 133.64 & 133.79 & 25.635 & 0.151 & 25.787 & 23.8 & 0.59 \\
Separator & 0.063 & 0.063 & 65.616 & 65.616 & 0.650 & 0 & 0.650 & 0 & 0 \\
$\quad \begin{array}{c}\text { Turbine } \\
\text { Expansion }\end{array}$ & 3.327 & 4.124 & 201.25 & 202.11 & 38.216 & 0.863 & 39.079 & 23.9 & 2.21 \\
$\quad$ valve & 0.063 & 0.063 & 22.867 & 22.867 & 0.103 & 0 & 0.103 & 0.45 & 0 \\
\hline
\end{tabular}

\subsection{Sensitivity Analysis}

\subsubsection{The Effects of the Ejector Inlet Temperature}

Figs. 8 to 11 illustrate changes in the ejector inlet temperature. By assuming that values $\mathrm{P}_{3}=9.75(\mathrm{MPa})$ and $\mathrm{T}_{7}=278.15(\mathrm{~K})$ are fixed, the ejector inlet temperature differences range considered between $312(\mathrm{~K})$ to $319(\mathrm{~K})$.

Figure 8 illustrates the exergy efficiency differences. The most decrease is related to HRRC-R744A and HRRC-R744 by $13 \%$ and 19\%, respectively. In Figure 9, COP changes have been assessed that by increasing $\mathrm{T}_{3}$, and the values of HRRC-R744 and HRRC-R744A decrease about $8 \%$ and $7 \%$, respectively.

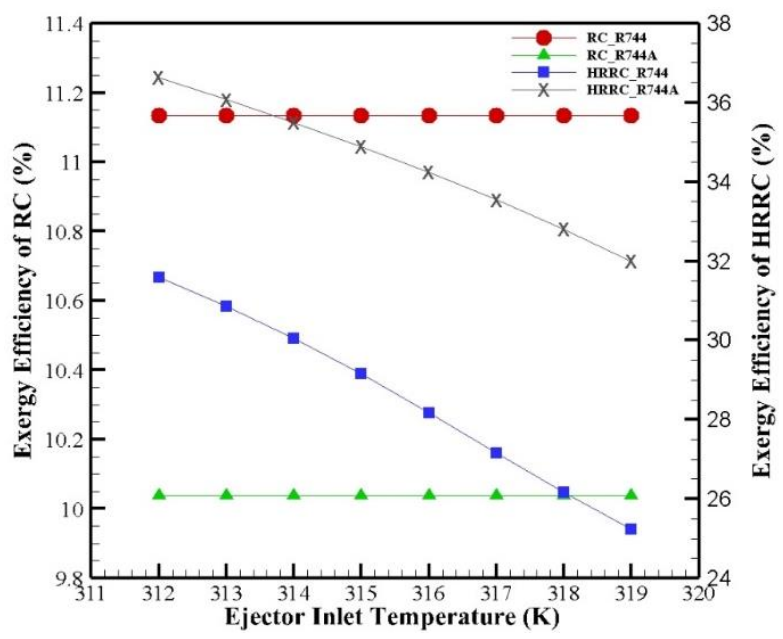

Figure 8. The effects of the ejector inlet temperature on the exergy efficiency for $R C$ and $H R R C$.

In Figs. 10 and 11, the product cost rate and the total cost rate changes are calculated. According to Figure10, as the ejector inlet temperature increases, the product cost rate in the HRRC decreases, which is the most substantial decrease in the HRRC-R744 cycle by about $29 \%$. The sensitivity analysis results in the RC cycle show that the product cost rate has increased slightly. According to Figure 11, the results obtained from the effects of changing the ejector inlet temperature on the total cost rate indicate that in the $\mathrm{RC}$, the total cost rate always increases with increasing the ejector inlet temperature, but in the
HRRC, the total cost rate decreases first and then increase. The most considerable change in the total cost rate belongs to the RC-R744 cycle by about $18 \%$.

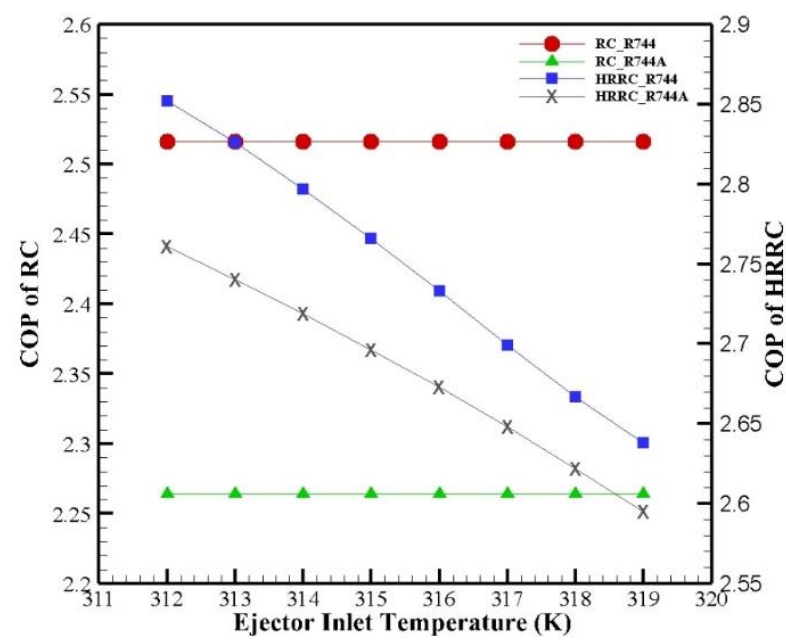

Figure 9. The effects of the ejector inlet temperature on COP for RC and HRRC.

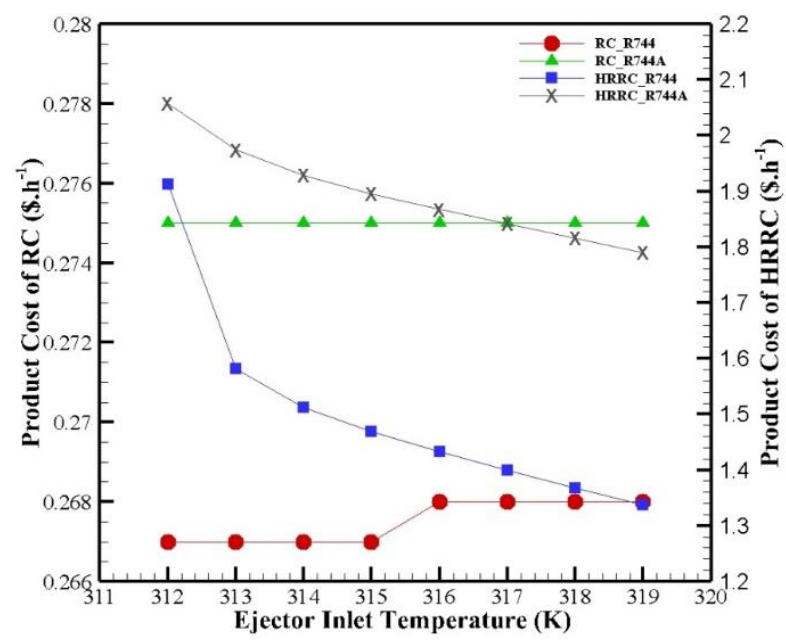

Figure 10. The effects of the ejector inlet temperature on the product cost rete for $R C$ and $H R R C$. 


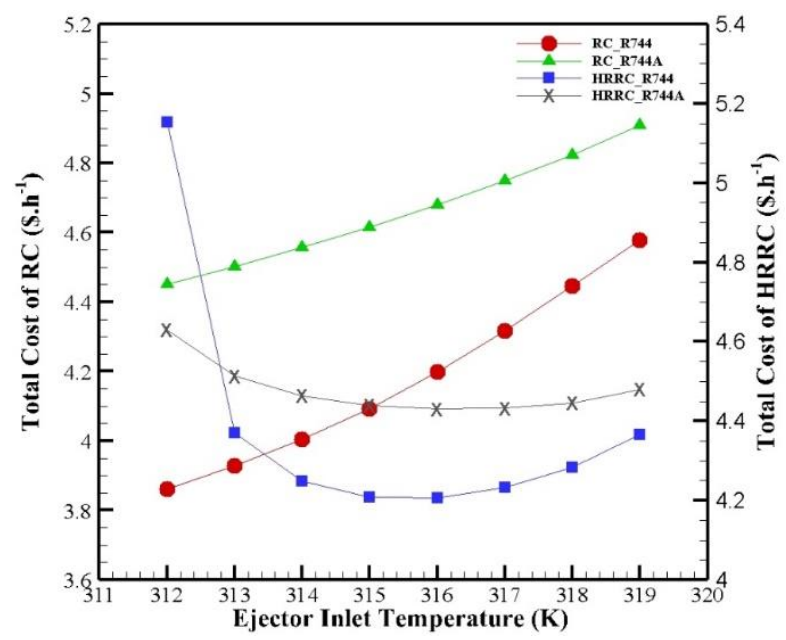

Figure 11. The effects of the ejector inlet temperature on the total cost rete for RC and HRRC.

By analysis, which has been done, it can be concluded that increasing the ejector inlet temperature causes an increase in destruction exergy, decreasing the operation of the cycle and increasing the total cost rate in a cooling capacity of $100(\mathrm{~kW})$ that all these factors are unfavorable thermodynamically and economically.

\subsubsection{The Effects of the Evaporator Outlet Temperature}

Figs. 12 to 15 illustrate the impact of increasing the evaporator outlet temperature for $\mathrm{R} 744 \mathrm{~A}$ and $\mathrm{R} 744$ working fluids of the RC and HRRC. The values of $\mathrm{T}_{3}=313.15(\mathrm{~K})$ and $\mathrm{P}_{3}=278.15(\mathrm{~K})$ are fixed for sensitivity analysis, and the variation range of the ejector outlet temperature is between $258(\mathrm{~K})$ to $278(\mathrm{~K})$.

Figs. 12 and 13 show the changes in the exergy efficiency and COP. The exergy efficiency and COP values for the cycles shown improvement with increasing evaporator outlet temperature. The HRRC has higher exergy efficiency than the RC due to the use of waste heatby-heat exchangers. The highest increase in exergy efficiency is related to RC-R744 by $40 \%$. In Figure 16, COP values increase with increasing $\mathrm{T}_{7}$, most of which related to HRRC-R744 by $58 \%$. The results show that increasing the evaporator outlet temperature reduces exergy destruction, which is one of the critical factors to cycle performance.

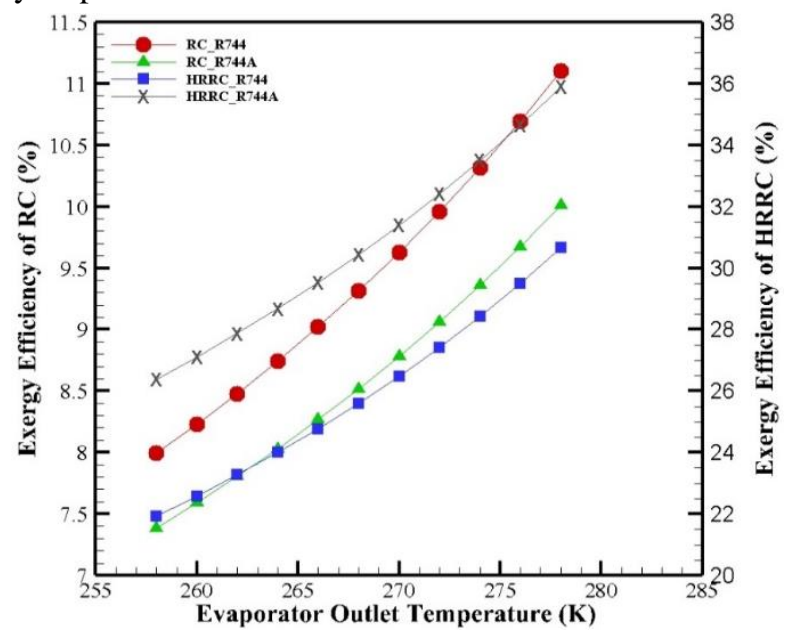

Figure 12. The effects of evaporator outlet temperature on the exergy efficiency for $R C$ and $H R R C$.

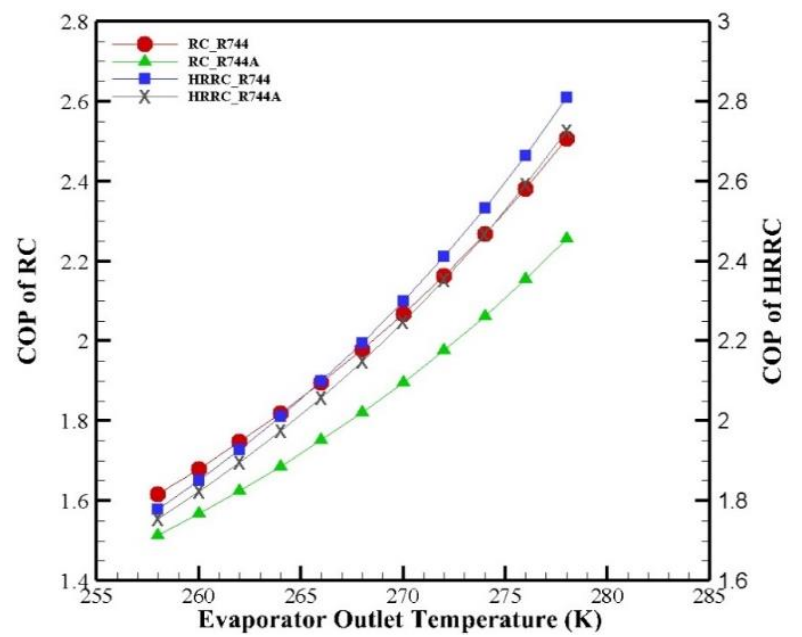

Figure 13. The effects of evaporator outlet temperature on the COP for RC and HRRC.

Figs. 14 and 15 illustrate the product cost rate and total cost rate changes according to the evaporator outlet temperature. By increasing $\mathrm{T}_{7}$ product cost rate and total cost rate will be decreased, and the most decrease of $\dot{C}_{P}$ is related to RC-R744 by $50 \%$, and the most decrease of $\dot{\mathrm{C}}_{\mathrm{T}}$ is for RC-R744 with the amount of $47 \%$. According to obtained results, by increasing the evaporator temperature, exergy efficiency and COP will be increased as well as product cost, and total cost will be decreased significantly. Therefore, it can be concluded that increasing the $\mathrm{T}_{7}$ is a suitable factor.

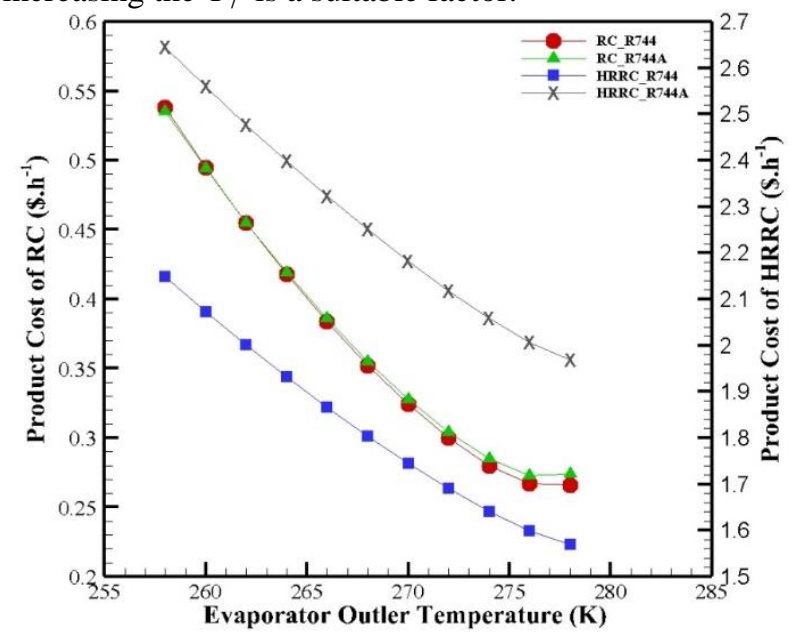

Figure 14. The effects of evaporator outlet temperature on the product cost rate for $R C$ and HRRC.

\subsection{Optimization Results}

The acquired results of HRRC multi-objective optimization with different working fluids and different objective functions are indicated as a Pareto frontier diagram by the usage of NSGA II. The decision variable boundaries are determined in Table 18. Figure 16 shows the optimization results by considering the objective functions of total product cost and exergy efficiency for $\mathrm{R} 744 \mathrm{~A}$ and $\mathrm{R} 744$. The total product cost rate is the best at $A$ and $D$ points, while these rates are unfavorable in other functions. The exergy efficiency is appropriate at $\mathrm{C}$ and $\mathrm{F}$ points while other functions are inappropriate. $\mathrm{B}$ and $\mathrm{E}$ points indicate the optimal values for two objective functions with R744A and R744. 


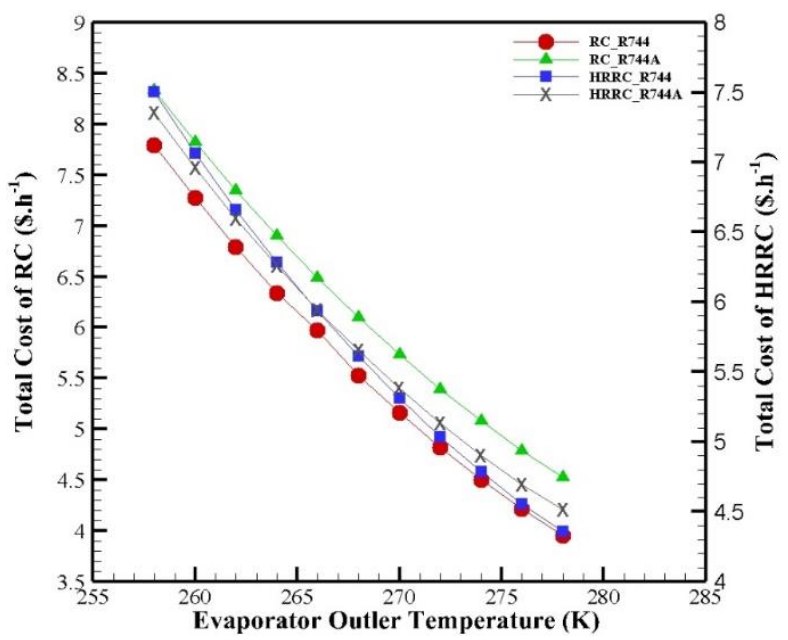

Figure 15. The effects of evaporator outlet temperature on the total cost rate for $R C$ and $H R R C$.

In Figure 17, optimization is done by COP and product environmental impact objective functions. According to the given description, $\mathrm{K}$ and $\mathrm{H}$ points are the optimal points selected for considered working fluids. The values of parameters that cause HRRC operation with R744 and R744A fluids at optimal points are given in Table 19 . According to present values in Table 19, although using R744A increases exergy efficiency by about 20 percent, it leads to a 28 percent increase in total product cost. The exergy efficiency for R744 and R744A is $28.51 \%$, and $34.44 \%$ also total product cost rate is about $1.44 \$ / \mathrm{h}$ and $1.85 \$ / \mathrm{h}$. Moreover, the optimization results with COP and product environmental impact objective functions represent that in the optimal case, the amount of COP for R744 and R744A working fluids is 2.67 and 2.76, and the value of product environmental impact is $149.01 \mathrm{mpts} / \mathrm{h}$ and $200.48 \mathrm{mpts} / \mathrm{h}$, respectively. In this case, utilizing $\mathrm{R} 744 \mathrm{~A}$, the COP rises by $3 \%$, but the cycle's environmental impact increases by more than $34 \%$.

Table 18. Decision variable boundaries for the optimal.

\begin{tabular}{cc}
\hline Decision variables & Feasibility values \\
\hline Compressor outlet pressure(MPa) & $9.4 \leq \mathrm{P}_{4} \leq 13.8$ \\
Ejector inlet Temperature $(\mathrm{K})$ & $312 \leq \mathrm{T}_{4} \leq 319$ \\
Evaporator outlet temperature $(\mathrm{K})$ & $258 \leq \mathrm{T}_{7} \leq 278$
\end{tabular}

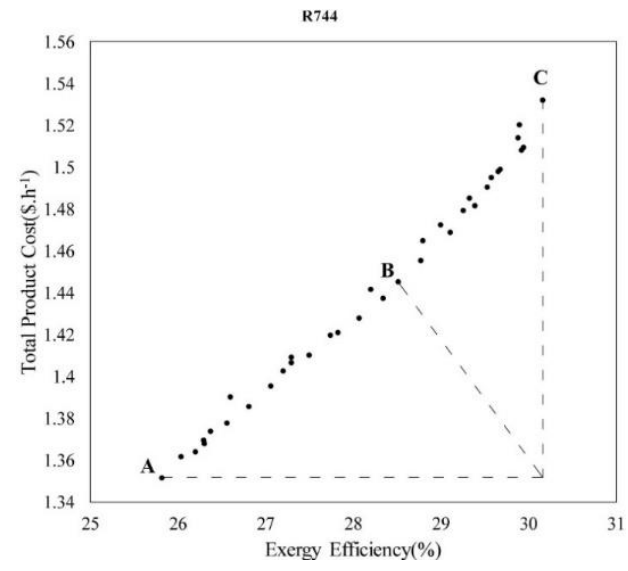

(a)

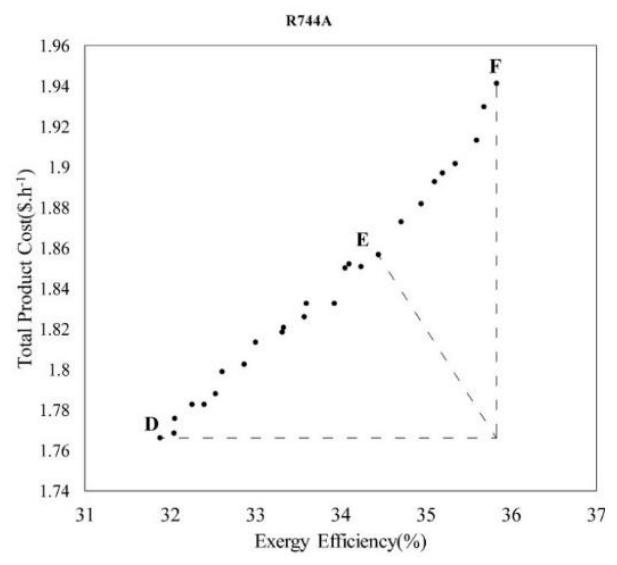

(b)

Figure 16. The Pareto frontier of the optimum solution with the exergy efficiency and product cost rate (a) $R 744$ and $(b)$ R744A.

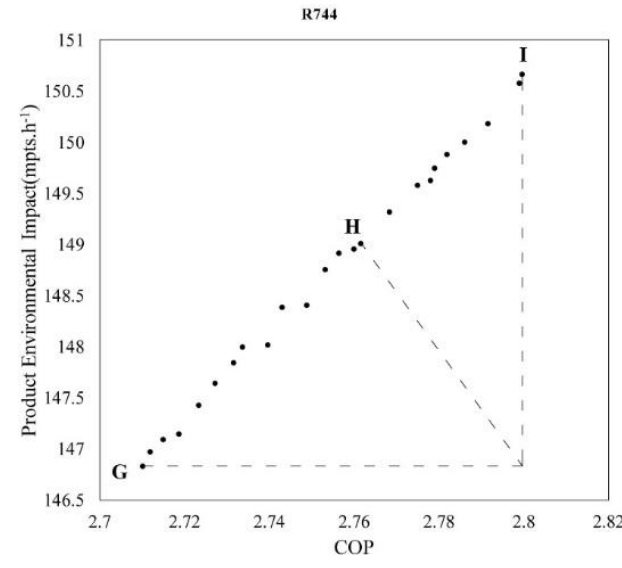

(a)

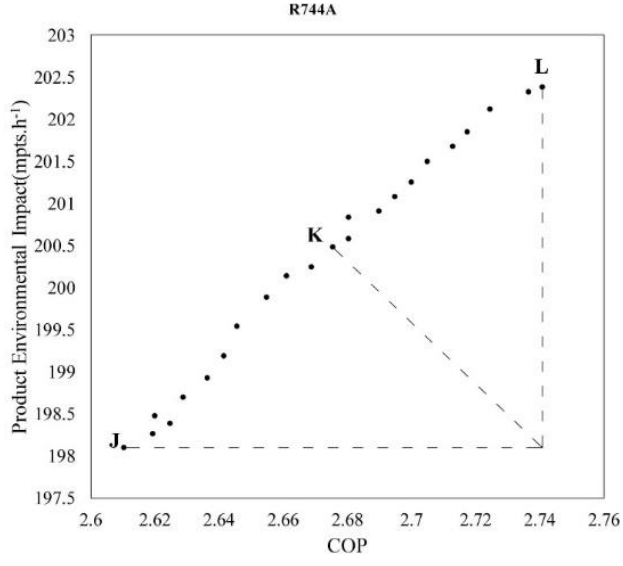

(b)

Figure 17. The Pareto frontier of the optimum solution with COP and product environmental impact (a) R744 and (b) R744A. 
Table 19. Optimized values of different design parameters.

\begin{tabular}{|c|c|c|c|c|c|c|}
\hline Parameters & The base case of 744 & The base case of 744A & $\mathrm{B}$ & $E$ & $\mathrm{H}$ & $\mathrm{K}$ \\
\hline Compressor outlet pressure(MPa) & 9.75 & 9.75 & 9.59 & 9.60 & 9.85 & 9.64 \\
\hline Ejector inlet Temperature(K) & 313 & 313 & 315.1 & 315.8 & 316.1 & 316.8 \\
\hline Evaporator outlet temperature $(\mathrm{K})$ & 278 & 278 & 277.4 & 277.9 & 278 & 278 \\
\hline Exergy efficiency $(\%)$ & 30.74 & 35.98 & 28.51 & 34.44 & - & - \\
\hline Total product $\operatorname{cost}(\$ / \mathrm{h})$ & 1.56 & 1.96 & 1.44 & 1.85 & - & - \\
\hline Coefficient of operation & 2.82 & 2.73 & - & - & 2.67 & 2.76 \\
\hline Product environment impact(mpts/h) & 154.03 & 204.25 & - & - & 149.01 & 200.482 \\
\hline
\end{tabular}

\section{Conclusion}

In the presented research, two refrigeration cycles are analyzed. In both cycles, the ejector is used, and their operations with R744 and R744A working fluids are compared. The most crucial goal in the analytical comparison of cycles is the impact of using loss heat in RC. Rankine cycle is used in the HRRC in order to increase the COP and exergy efficiency. Therefore, heat recovery is used in HRRC. After checking the first and second thermodynamic laws and proving the benefits of HRRC compared to RC for both working fluids, other thermodynamic analyses such as exergoeconomic, exergoenvironmental, advanced exergy, and optimization for HRRC has been done that their results are given below.

1. The results of energy analysis indicate that COP in RC with R744 and R744A fluids is 2.51 and 2.26 also for HRRC is 2.82 and 2.73. Using R744 indicates more values for both cycles, and using the HRRC improves COP for R744A and R744, about $11 \%$ and 17\%, respectively.

2. The exergy analysis results of RC with R744A and R744 working fluids indicate the exergy efficiency is about $11 \%$ and $10 \%$, and for the HRRC is about $30.7 \%$ and $35.9 \%$.

3. The value of $\dot{C}_{P}$ for R744 and R744A fluids is obtained $1.56 \$ / \mathrm{h}$ and $1.96 \$ / \mathrm{h}$ and for $\dot{C}_{T}$ is about 4.34 $\$ / \mathrm{h}$ and $4.5 \$ / \mathrm{h}$. By checking the exergoeconomic results of HRRC. R744 is advantageous economically.

4. The exergoenvironmental analysis is done on HRRC indicates that the highest environmental impact of both working fluids is for the compressor. The product environmental impact for R744 and R744A is about 154 $\mathrm{mpts} / \mathrm{h}$ and $204 \mathrm{mpts} / \mathrm{h}$. It means that the product of R744A has impacts that are more destructive on the environment.

5. The advanced exergy analysis shows that the unavoidable exergy is higher than the avoidable part. The avoidable endogenous exergy destruction is more than an exogenous part of it; therefore, to improve the exergy destruction, avoidable endogenous exergy destruction of each component should be decreased.

6. In order to define the optimal case of HRRC system operation, multi-objective optimization with different objective functions has been done. In the optimal case, exergy efficiency for R744 and R744A is $28.51 \%$, and $34.44 \%$ also total product cost rate is about $1.44 \$ / \mathrm{h}$ and
$1.85 \$ / \mathrm{h}$. The optimization results with COP and product environmental impact objective functions indicate that in the optimal case, the amount of COP for R744 and R744A working fluids is 2.67 and 2.76 , and the value of $\dot{B}_{P}$ is $149.01 \mathrm{mpts} / \mathrm{h}$ and $200.48 \mathrm{mpts} / \mathrm{h}$, respectively.

7. The sensitivity analysis results indicate that increasing the evaporator's outlet temperature improves exergy efficiency while decreasing the total and product cost rate, leading to a cost-effective cycle.

\section{Nomenclature}

$\begin{array}{cc}\mathrm{A} & \text { Heat transfer area }\left(\mathrm{m}^{2}\right) \\ \dot{\mathrm{B}} & \text { Environmental impact rate }(\mathrm{mpts} / \mathrm{h}) \\ \dot{B}_{D} & \text { Destruction environmental impact rate } \\ & (\text { mpts/h) } \\ \mathrm{b} & \text { Unit environmental impact }(\mathrm{mpts} / \mathrm{MJ}) \\ \mathrm{c} & \text { Unit cost of exergy }(\$ / \mathrm{MJ}) \\ \dot{C} & \text { Cost rate }(\$ / \text { hour }) \\ \dot{C}_{D} & \text { Destruction cost rate }(\$ / \mathrm{hour}) \\ \dot{C}_{P} & \text { Production cost rate }(\$ / \mathrm{hour}) \\ \dot{C}_{\text {total }} & \text { Total cost rate }(\$ / \mathrm{hour}) \\ \mathrm{c}_{\mathrm{p}} & \text { Specific heat }(\mathrm{kJ} / \mathrm{kg} \mathrm{K}) \\ \mathrm{CCHP} & \text { Combined cooling heating and power } \\ \mathrm{COP} & \text { Coefficient of performance } \\ \mathrm{CRF} & \text { Capital recovery factor } \\ \dot{E} & \text { Energy rate }(\mathrm{kW}) \\ \dot{E} X & \text { Exergy rate }(\mathrm{kW}) \\ \mathrm{f}_{\mathrm{b}} & \text { Exergoenvironmental factor } \\ \mathrm{f}_{\mathrm{c}} & \text { Exergoeconomic factor } \\ \mathrm{FS} & \text { Factor of safety } \\ \mathrm{h} & \text { Specific enthalpy }(\mathrm{kJ} / \mathrm{kg}) \\ \mathrm{HRRC} & \text { Heat recovery refrigeration cycle } \\ \mathrm{L} & \text { Loss } \\ \mathrm{LCA} & \text { Life cycle assessment } \\ \dot{m} & \text { Mass flow rate }(\mathrm{kg} / \mathrm{s}) \\ \mathrm{n} & \text { Component lifetime }(\mathrm{year}) \\ \mathrm{ORC} & \text { Organic Rankine cycle } \\ \mathrm{P} & \text { Pressure }(\mathrm{kPa}) \\ \mathrm{r}_{\mathrm{b}} & \text { Relative environmental impacts difference } \\ \mathrm{r}_{\mathrm{c}} & \text { Relative cost difference }(\%) \\ \mathrm{RC} & \text { Refrigeration cycle } \\ \mathrm{s} & \text { Tpecific entropy }(\mathrm{kJ} / \mathrm{kg} \mathrm{K}) \\ \mathrm{T} & \text { Time }(\mathrm{h}) \\ \mathrm{V} & \text { Heat transfer coefficient }\left(\mathrm{W} / \mathrm{K} \text { m }{ }^{2}\right) \\ & \text { Welocity }(\mathrm{m} / \mathrm{s}) \\ \mathrm{H} & \text { Ton) }\end{array}$




$\dot{W}$
$\dot{Y}$
$\dot{Z}$
$\mathrm{Z}^{\mathrm{cl}}$

$\Upsilon_{\mathrm{D}, \mathrm{k}}$
$\eta$
$\mu$
$\rho$
$\sigma$
$\varphi$

0
$\mathrm{a}$
$\mathrm{AV}$
$\mathrm{Ch}$
$\mathrm{D}$
$\mathrm{e}$
$\mathrm{EN}$
$\mathrm{EX}$
$\mathrm{f}$
$\mathrm{F}$
$\mathrm{i}$
$\mathrm{P}$
$\mathrm{Ph}$
$\mathrm{UN}$

Subscripts and Superscripts

\author{
Dead state \\ Ambient \\ Avoidable \\ Chemical \\ Destruction \\ Output \\ Endogenous \\ Exogenous \\ Fluid \\ Fuel \\ Input \\ Product \\ Physical \\ Unavoidable
}

\section{References}

[1] Y. Demirel, "Thermodynamic analysis," Arabian Journal for Science and Engineering, vol. 38, no. 2, pp. 221-249, 2013.

[2] O. Ipakchi, A. Mosaffa, and L. G. Farshi, "Ejector based $\mathrm{CO} 2$ transcritical combined cooling and power system utilizing waste heat recovery: A thermoeconomic assessment," Energy Conversion and Management, vol. 186, pp. 462-472, 2019.

[3] A. Z. Miran, A. Nemati, and M. Yari, "Performance analysis and exergoeconomic evaluation of a TRC system enhanced by a dedicated mechanical subcooling," Energy Conversion and Management, vol. 197, p. 111890, 2019.

[4] C. Seckin, "Parametric analysis and comparison of ejector expansion refrigeration cycles with constant area and constant pressure ejectors," Journal of Energy Resources Technology, vol. 139, no. 4, 2017.

[5] C. Seckin, "Effect of Operational Parameters on a Novel Combined Cycle of Ejector Refrigeration Cycle and Kalina Cycle," Journal of Energy Resources Technology, vol. 142, no. 1, 2020.

[6] A. Ahmadzadeh, M. R. Salimpour, and A. Sedaghat, "Thermal and exergoeconomic analysis of a novel solar driven combined power and ejector refrigeration (CPER) system," International Journal of refrigeration, vol. 83, pp. 143-156, 2017.

[7] H. R. Takleh and V. Zare, "Performance improvement of ejector expansion refrigeration cycles employing a booster compressor using different refrigerants: Thermodynamic analysis and optimization," International Journal of Refrigeration, vol. 101, pp. 56-70, 2019.

[8] K. Megdouli, B. Tashtoush, E. Nahdi, M. Elakhdar, A. Mhimid, and L. Kairouani, "Performance analysis of a combined vapor compression cycle and ejector cycle for refrigeration cogeneration," International Journal of Refrigeration, vol. 74, pp. 517-527, 2017.

[9] K. Megdouli, B. Tashtoush, Y. Ezzaalouni, E. Nahdi, A. Mhimid, and L. Kairouani,
"Performance analysis of a new ejector expansion refrigeration cycle (NEERC) for power and cold: Exergy and energy points of view," Applied Thermal Engineering, vol. 122, pp. 39-48, 2017.

[10] A. Nemati, H. Nami, and M. Yari, "A comparison of refrigerants in a two-stage ejectorexpansion transcritical refrigeration cycle based on exergoeconomic and environmental analysis," International Journal of Refrigeration, vol. 84, pp. 139-150, 2017.

[11] H. Momeni and M. M. Keshtkar, "Thermodynamic, Economic, and Environmental Comparison Between the Direct and Indirect $\mathrm{CO} 2$ Refrigeration Cycle With Conventional Indirect NH3 Cycle With Considering a Heat Recovery System in an Ice Rink: A Case Study," Journal of Energy Resources Technology, vol. 142, no. 1, 2020.

[12] S. Khanmohammadi, M. Goodarzi, S. Khanmohammadi, and H. Ganjehsarabi, "Thermoeconomic modeling and multi-objective evolutionary-based optimization of a modified transcritical $\mathrm{CO} 2$ refrigeration cycle," Thermal Science and Engineering Progress, vol. 5, pp. 86-96, 2018.

[13] K. G. Mofrad, S. Zandi, G. Salehi, and M. H. K. Manesh, "4E Analyses and Multi-Objective Optimization of Cascade Refrigeration Cycles with Heat Recovery System," Thermal Science and Engineering Progress, p. 100613, 2020.

[14] K. Megdouli, H. Sahli, B. Tashtoush, E. Nahdi, and L. Kairouani, "Theoretical research of the performance of a novel enhanced transcritical $\mathrm{CO} 2$ refrigeration cycle for power and cold generation," Energy Conversion and Management, vol. 201, p. 112139, 2019.

[15] B. Ghorbani, M. Mehrpooya, and M. M. M. Sharifzadeh, "Introducing a hybrid photovoltaicthermal collector, ejector refrigeration cycle and phase change material storage energy system (Energy, exergy and economic analysis)," International Journal of Refrigeration, vol. 103, pp. 61-76, 2019.

[16] M.-H. Hamedi, R. Shirmohammadi, B. Ghorbani, and S. Sheikhi, "Advanced exergy 
evaluation of an integrated separation process with optimized refrigeration system," Gas Processing Journal, vol. 3, no. 1, pp. 1-10, 2015.

[17] T. Bai, J. Yu, and G. Yan, "Advanced exergy analyses of an ejector expansion transcritical $\mathrm{CO} 2$ refrigeration system," Energy conversion and management, vol. 126, pp. 850-861, 2016.

[18] T. Bai, J. Yu, and G. Yan, "Advanced exergy analysis on a modified auto-cascade freezer cycle with an ejector," Energy, vol. 113, pp. 385398, 2016.

[19] J. Chen, K. Zhu, Y. Huang, Y. Chen, and X. Luo, "Evaluation of the ejector refrigeration system with environmentally friendly working fluids from energy, conventional exergy and advanced exergy perspectives," Energy Conversion and Management, vol. 148, pp. 1208-1224, 2017.

[20] V. Ghazizadeh, B. Ghorbani, R. Shirmohammadi, M. Mehrpooya, and M. H. Hamedi, "Advanced Exergoeconomic Analysis of C3MR, MFC and DMR Refrigeration Cycles in an Integrated Cryogenic Process," Gas Processing Journal, vol. 6, no. 1, pp. 41-71, 2018.

[21] M. Moghimi, M. Emadi, P. Ahmadi, and H. Moghadasi, "4E analysis and multi-objective optimization of a CCHP cycle based on gas turbine and ejector refrigeration," Applied Thermal Engineering, vol. 141, pp. 516-530, 2018.

[22] S. Sanaye, A. Farvizi, A. Refahi, and M. V. Rafieinejad, "A novel application of optimization and computational fluid dynamics methods for designing combined ejectorcompressor refrigeration cycle," International Journal of Refrigeration, vol. 108, pp. 174-189, 2019.

[23] H. Zhao, T. Yuan, J. Gao, X. Wang, and J. Yan, "Conventional and advanced exergy analysis of parallel and series compression-ejection hybrid refrigeration system for a household refrigerator with R290," Energy, vol. 166, pp. 845-861, 2019.

[24] M. Esmaeilzadehazimi, M. H. K. Manesh, B. B. Heleyleh, and H. V. Modabbaer, "4E Analysis of Integrated MHD-Combined Cycle," International Journal of Thermodynamics, vol. 22, no. 4, pp. 219-228, 2019.

[25] S. Sanaye, M. Amani, and P. Amani, "4E modeling and multi-criteria optimization of CCHPW gas turbine plant with inlet air cooling and steam injection," Sustainable Energy Technologies and Assessments, vol. 29, pp. 7081, 2018.

[26] S. Adibhatla and S. Kaushik, "Energy, exergy, economic and environmental (4E) analyses of a conceptual solar aided coal fired $500 \mathrm{MWe}$ thermal power plant with thermal energy storage option," Sustainable Energy Technologies and Assessments, vol. 21, pp. 89-99, 2017.

[27] A. Jahangiri and M. Ameri, "Interaction effects of natural draft dry cooling tower (NDDCT) performance and 4E (energy, exergy, economic and environmental) analysis of steam power plant under different climatic conditions,"
Sustainable Energy Technologies and Assessments, vol. 37, p. 100599, 2020.

[28] P. Gullo and A. Hafner, "Thermodynamic performance assessment of a $\mathrm{CO} 2$ supermarket refrigeration system with auxiliary compression economization by using advanced exergy analysis," International Journal of Thermodynamics, vol. 20, no. 4, pp. 220-227, 2017.

[29] H. V. MODABBER and M. H. K. MANESH, "4E Analysis of Power and Water Cogeneration Plant based on Integrated MED-TVC and RO Desalination Units," International Journal of Thermodynamics, vol. 23, no. 2, pp. 107-126.

[30] N. H. Gay, "Refrigerating system," ed: Google Patents, 1931.

[31] A. Khaliq, "Energetic and exergetic performance investigation of a solar based integrated system for cogeneration of power and cooling," Applied Thermal Engineering, vol. 112, pp. 1305-1316, 2017.

[32] K. Megdouli, N. Ejemni, E. Nahdi, A. Mhimid, and L. Kairouani, "Thermodynamic analysis of a novel ejector expansion transcritical CO2/N2O cascade refrigeration (NEETCR) system for cooling applications at low temperatures," Energy, vol. 128, pp. 586-600, 2017.

[33] D. Y. Goswami, The CRC handbook of mechanical engineering. CRC press, 2004.

[34] A. Bejan, G. Tsatsaronis, and M. Moran, "Thermal Design and Optimization John Wiley and Sons," Inc. New York, 1996.

[35] S. Zandi, K. G. Mofrad, G. Salehi, M. H. K. Manesh, and A. Fazeli, "Multi-objective optimization and thermoeconomic analysis of a novel CCHP with TES and hybrid cooling for residential complex," Thermal Science and Engineering Progress, p. 100656, 2020.

[36] J. Wang, Y. Dai, and Z. Sun, "A theoretical study on a novel combined power and ejector refrigeration cycle," International Journal of Refrigeration, vol. 32, pp. 1186-1194, 2009.

[37] T. Parikhani, H. Azariyan, R. Behrad, H. Ghaebi, and J. Jannatkhah, "Thermodynamic and thermoeconomic analysis of a novel ammoniawater mixture combined cooling, heating, and power (CCHP) cycle," Renewable Energy, vol. 145, pp. 1158-1175, 2020.

[38] F. Mohammadkhani, N. Shokati, S. Mahmoudi, M. Yari, and M. Rosen, "Exergoeconomic assessment and parametric study of a Gas Turbine-Modular Helium Reactor combined with two Organic Rankine Cycles," Energy, vol. 65, pp. 533-543, 2014.

[39] A. Mosaffa, L. G. Farshi, C. I. Ferreira, and M. Rosen, "Exergoeconomic and environmental analyses of $\mathrm{CO} 2 / \mathrm{NH} 3$ cascade refrigeration systems equipped with different types of flash tank intercoolers," Energy Conversion and Management, vol. 117, pp. 442-453, 2016.

[40] X. Zhang, R. Zeng, K. Mu, X. Liu, X. Sun, and $\mathrm{H}$. Li, "Exergetic and exergoeconomic evaluation of co-firing biomass gas with natural gas in CCHP system integrated with ground 
source heat pump," Energy conversion and management, vol. 180, pp. 622-640, 2019.

[41] A. Khosravi, R. Koury, and L. Machado, "Thermo-economic analysis and sizing of the components of an ejector expansion refrigeration system," International Journal of Refrigeration, vol. 86, pp. 463-479, 2018.

[42] P. Ahmadi, I. Dincer, and M. A. Rosen, "Exergy, exergoeconomic and environmental analyses and evolutionary algorithm based multiobjective optimization of combined cycle power plants," Energy, vol. 36, pp. 5886-5898, 2011.

[43] K. Yang, N. Zhu, Y. Ding, C. Chang, D. Wang, and T. Yuan, "Exergy and exergoeconomic analyses of a combined cooling, heating, and power (CCHP) system based on dual-fuel of biomass and natural gas," Journal of Cleaner Production, vol. 206, pp. 893-906, 2019.

[44] M. H. Khoshgoftar Manesh and E. Jadidi, "Conventional and advanced exergy, exergoeconomic and exergoenvironmental analysis of a biomass integrated gasification combined cycle plant," Energy Sources, Part A: Recovery, Utilization, and Environmental Effects, pp. 1-22, 2020.

[45] M. K. Manesh, P. Navid, A. B. Marigorta, M. Amidpour, and M. Hamedi, "New procedure for optimal design and evaluation of cogeneration system based on advanced exergoeconomic and exergoenvironmental analyses," Energy, vol. 59, pp. 314-333, 2013.

[46] H. Khosravi, G. R. Salehi, and M. T. Azad, "Design of structure and optimization of organic Rankine cycle for heat recovery from gas turbine: The use of 4E, advanced exergy and advanced exergoeconomic analysis," Applied Thermal Engineering, vol. 147, pp. 272-290, 2019.

[47] E. J. C. Cavalcanti, "Exergoeconomic and exergoenvironmental analyses of an integrated solar combined cycle system," Renewable and Sustainable Energy Reviews, vol. 67, pp. 507519, 2017.

[48] L. Meyer, G. Tsatsaronis, J. Buchgeister, and L. Schebek, "Exergoenvironmental analysis for evaluation of the environmental impact of energy conversion systems," Energy, vol. 34, pp. 75-89, 2009.

[49] M. K. Manesh et al., "Exergoeconomic and exergoenvironmental evaluation of the coupling of a gas fired steam power plant with a total site utility system," Energy Conversion and Management, vol. 77, pp. 469-483, 2014. 